\title{
Spatial Ecology Applied to Identify Differential Uses of Habitat Types and Hotspots of Amazon River Dolphin Activity
}

Federico Mosquera Guerra ( $\square$ federico.mosqueraguerra@gmail.com )

Pontificia Universidad Javeriana

Fernando Trujillo

Fundación Omacha

Jairo Pérez-Torres

Pontificia Universidad Javeriana

Hugo Mantilla-Meluk

Universidad del Quindío

Nicole Franco

Fundación Omacha

María Jimena Valderrama

Fundación Omacha

Estefany Acosta-Lugo

Universidad Militar Nueva Granada

Paula Torres-Forrero

Fundación Omacha

José Saulo Usma Oviedo

World Wildlife Fund

Sebastian Barreto

Universidad Nacional de Colombia

Dolors Armenteras-Pascual

Universidad Nacional de Colombia

\section{Research Article}

Keywords: Core area, heterogeneity, home range, Neotropical rivers, small cetaceans, spatiotemporal distribution

Posted Date: October 13th, 2021

DOl: https://doi.org/10.21203/rs.3.rs-963127/v1 
License: (c) (i) This work is licensed under a Creative Commons Attribution 4.0 International License. Read Full License 


\section{Abstract}

Context: Identifying the heterogeneity in the habitat use and hotspots of Amazon River dolphin activity is essential to design effective strategies for the management and conservation of these cetaceans and their habitats in the Colombian Amazonas River and Orinoco basin.

Objectives: Quantify the differential use of habitat that Amazon River dolphins exhibit and to identify hotspot activity during seasons of rising waters in the Colombian Amazonas River and other major rivers in the Orinoco basin.

Methods: Based on processed satellite images Landsat 8 (2018-2022), we classified habitat types used by I. geoffrensis and reported in the literature: (1) main river, (2) confluences, (3) tributaries, (4) channels, (5) islands, (6) bays, and (7) lagoons. We combined this dataset with GPS location data obtained from 17 tagged Amazon River dolphins to quantify the proportion of habitat types used, and we used GAMLSS to explore the relationship between the number of locations per habitat as the predictor variable and nine response variables. Kernel density estimate $(\mathrm{KDE})$ analysis was used to identify both areas used $\left(\mathrm{K}_{95}\right)$ and hotspot activity associated with core areas $\left(\mathrm{K}_{50}\right)$ in the habitat types for the individuals monitored in the Amazonas River and Orinoco basin.

Results: Satellite tracking of I. geoffrensis individuals reported 16.098 locations (Amazonas River, $\mathrm{n}=$ 2.934 locations and Orinoco basin, $n=13.164$ locations) classified into seven habitat types. For the analyzed period (rising waters) main habitat types used were as follow: in the Amazonas River (1) main river $(n=1.346,46 \%)$, and (2) lagoons $(n=1.158,39 \%)$; and in the Orinoco basin ( 1$)$ main river $(n=7.798$, $59.2 \%)$, and (2) channels ( $n=1.535,11.7 \%)$. The best fitting GAMLSS for the I. geoffrensis monitored individuals in the Amazonas River showed that body length, sex, and habitat types (lagoons and main river) were significant predictors of Amazon River dolphins; and in the Orinoco basin they showed that body length, longest distance, $\mathrm{K}_{50}$, and habitat types (confluences, lagoons, main river, and tributaries) were significant. Individuals monitored in the areas evaluated in the Amazonas River reported $\mathrm{K}_{95}$ ranged: $30.7-105.5 \mathrm{~km}^{2}$ (mean $=62 \pm 32$ ), and the $\mathrm{K}_{50}$ or hotspots of activity were recorded in the main river, confluences, lagoons, and tributaries. In the five rivers of the Orinoco basin, monitored individuals registered $\mathrm{K}_{95}$ ranged: $6-116 \mathrm{~km}^{2}$ (mean $=32.8 \pm 31.53$ ), and hotspots of activity were recorded in the main river, islands, channels, confluences, bays, tributaries, and lagoons.

Conclusions: Evaluation of differences in habitat type use and identification of hotspot activity will contribute to improving management and conservation efforts for the populations of these cetaceans in the Colombian Amazonas and Orinoco basins.

\section{Introduction}

The space animals use to live and reproduce, commonly known as the 'home range', is considered a fundamental metric in animal ecology (Kenward 2001; Hemson et al. 2005; Börger et al. 2008; Viana et al. 
2018). Home range is defined by the interactions between animals and their environment; and its size is directly related to animal movement, and by intrinsic factors related to the individual's state of development, habitat selection, and other biotic interactions (e.g., predation and competition; Gubbins 2002; Buskirk 2004; Börger et al. 2008; Knight et al. 2009; Oullette and Cardinalle 2011; Tucker et al. 2014; Viana et al. 2018). Home ranges are not occupied homogeneously (Mosquera-Guerra et al. 2021); some areas are used more frequently (called 'core areas') and are often associated with greater resource density (Powell 2000; Oshima et al. 2010).

Home range studies have been focused primarily on terrestrial species, analyzing habitat selection and use; and these studies have allowed us to gain important insights into the spatiotemporal distribution of resources and the use of core area and hotspot sizes (Relyea et al. 2000; Di Bitetti 2001). The intrinsic difficulties in analyzing the spatial ecology of aquatic fauna have prevented us from understanding those factors determining the spatial-temporal patterns of resource availability and how they are used by aquatic animal communities (Mosquera-Guerra et al. 2021). This is particularly true for riverine ecosystems that are characterized by greater dynamics and are influenced by flood pulses and other climatic, geographic, and ecological determinants (Barthem et al. 2017).

A major challenge for aquatic species is to efficiently, continuously, and quantifiably monitor behaviors (Di Bitetti 2001; Ager et al. 2003; Di Blanco et al. 2017). Recently, the use of remote tracking technology on wild animals has provided remarkable insights into how, when, and where animals move (Hussey et al. 2015; Kays et al. 2015; Van Toor et al. 2018; Mosquera-Guerra et al. 2021). The study of spatial ecology of the endangered Amazon River dolphin (I. geoffrensis) employs a wide variety of techniques to study habitat uses. This includes tracking individually marked animals (e.g., Trujillo 1994; Martin and da Silva 2004; McGuire and Henningsen 2007; Gómez-Salazar et al. 2011; Mintzer et al. 2016), radio-telemetric techniques (e.g., Martin and da Silva 1998; 2004a), passive acoustic studies (e.g., Yamamoto et al. 2015), aerial surveys (e.g., Fürstenau-Oliveira et al. 2017; Oliveira-da-Costa et al. 2019), and satellite-telemetric tracking (e.g., Mosquera-Guerra et al. 2021). Inia is the only genus in the family Iniidae (Odontoceti. Cetacea), one of four families of river dolphins (da Silva and Martin 2014; 2018). Inia geoffrensis is subdivided into two subspecies $\mathrm{l}$. g. geoffrensis distributed across the Amazon and Orinoco basins and $I$. g. boliviensis, found along the Mamoré, Iténez, and Madeira rivers (Banguera-Hinestroza et al. 2002; Gravena et al. 2014; Hrbek et al. 2014; da Silva et al. 2018). The Amazon River dolphin is the largest of the river dolphins with a maximum recorded body length of $255 \mathrm{~cm}$ and a mean body mass of $207 \mathrm{~kg}$ for males and $225 \mathrm{~cm}$ and $153 \mathrm{~kg}$ for females, and it is also the most sexually dimorphic river dolphin; males are $16 \%$ longer and 55\% heavier than females (Martin and da Silva 2006; da Silva and Martin 2014).

The Amazon River dolphin is considered one of the top predators of the aquatic trophic webs of the Amazon, Orinoco, and Araguaia-Tocantins basins (McGuire \& Winemiller 1998; Gómez-Salazar et al. 2012). Inia geoffrensis is listed as endangered (EN) by the International Union for Conservation of Nature (IUCN; da Silva et al. 2018), and the species is included in Appendix II of the Convention on International Trade in Endangered Species of Wild Fauna and Flora (CITES; da Silva et al. 2018). The species is considered among the most threatened aquatic mammals globally (Reeves et al. 2003; Trujillo et al. 
2010). Populations are declining due to (1) bycatch and targeted killing because of fisheries conflict or consumption of their meat (Trujillo et al. 2010; Mintzer et al. 2016, 2018; da Silva et al. 2018; Brum et al. 2021); (2) habitat degradation through timber exploitation, agricultural expansion, and gold mining (Mosquera-Guerra et al. 2019); (3) climate change (Mosquera-Guerra et al. 2019a); and (4) the construction of hydropower dams, particularly in Brazil, Peru and Bolivia (Anderson et al. 2019; Brum et al. 2021).

In the current context, biodiversity in freshwater ecosystems is in rapid decline. It is considered even more threatened compared to that of terrestrial and marine ecosystems (Revenga et al. 2000; Vörösmarty et al. 2010). Decline in many large mammal migratory populations on regional and global scales has been reported (Berger 2004; Bolger et al. 2008; Newmark 2008; Sawyer et al. 2009; Newak and Rickart 2012), especially species with extensive and heterogeneous area requirements (Soulé and Terborgh 1999; Newak and Rickart 2012) such as neotropical aquatic mammals (Brum et al. 2021; Mosquera-Guerra et al. 2021). It is urgent to quantify the heterogeneity in habitat use in areas occupied by this mammal for localities critical for conservation of the species (Morris 2003; Preisler et al. 2006; Nina et al. 2008; Newak and Rickart 2012; Mosquera-Guerra et al. 2021). Understanding habitat use and spatial distribution of aquatic mammals is important for the application of management and conservation, such as protected area design (Morris 2003; Nina et al. 2008; Kong et al. 2018), management of threatened populations (Seminoff et al. 2002), identification of overlap with anthropogenic impacts (Soulé and Terborgh 1999; Chetkiewicz et al. 2006; Rayment et al. 2009; Newak and Rickart 2012), and improving our understanding of landscape connectivity (Crooks and Sanjayan 2006; Newak and Rickart 2012).

In this paper, we identify the types of hábitats used by 17 Amazon River dolphins using deployed satellite tracking transmitters receiving individual locations. Locations reported by the monitored individuals were classified by habitat types, allowing for the quantification of habitat use and for determining the core areas or hotspots of activity and their size. The identification of hotspots can offer a reference for scientifically defining prioritized areas for conservation, an aspect that is fundamental when allocating limited resources to the process of ecosystem management (Reyers et al. 2009; Zhang and Fu 2014).

\section{Study area}

We conducted this study from October 2017 to May 2021 across six Colombian rivers located in the following localities: (1) Amazonas, (2) Arauca, (3) Bita, (4) Guayabero, (5) Guaviare, and (6) Orinoco (see Fig. 1a-f). Transects evaluated in the rivers where the different habitat types were classified covered 247 $\mathrm{km}^{2}$ for the Amazonas River and $428 \mathrm{~km}^{2}$ for the Orinoco basin. Transects were defined through the Amazon River dolphin home range sizes, satellite-monitored in the following localities: (1) Amazonas River, from the confluence of the Atacuari and the Amazonas River in Colombia to Zaragoza Creek, including the Tarapoto wetland complex, and the confluence of the Loretoyacu and the Amazonas rivers (see Fig. 1a); (2) Orinoco River, from the mid-basin of the Orinoco River in Colombia, including its confluences with the Bita and Meta rivers, Negro Creek, El Pañuelo Island, and San José, Angela, and Guaripa creeks (see Fig. 1b); (3) Arauca River, from mid basin of the Arauca River, including El Martinero 
Creek, to Jesús Creek (see Fig. 1c); (iv) Bita River, from the lower basin of the Bita River from La Pinzonera Creek to the confluence of the Bita and Orinoco rivers and EI Pañuelo Island in the Orinoco River (see Fig. 1d); (v) Guayabero River, from Temblón Creek, including Yarumales Creek to Yuca Creek (see Fig. 1e), and (vi) Guavire River, from La Laguna Ciega, including the confluence of the Guaviare and Inírida rivers, to El Carbón Creek (see Fig. 1f).

\section{Methods}

Location data

River dolphin tagging was carried out during the rising water season for the Colombian Amazonas River

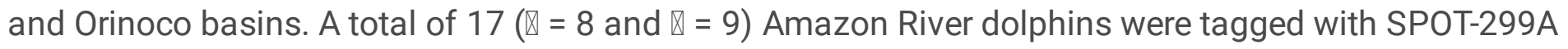
and SPOT6-F single-point fin mounted satellite tags (Wildlife Computers, Redmond, WA). Only adult individuals were selected for tagging, and their age class was estimated based on body length, following the methods of da Silva (2009) and Martin and da Silva (2018) and avoiding females with calves (see Table S1). The tags were programmed for continuous transmission (24 hours) up to 250 times a day from an ARGOS satellite constellation, providing location and tag status data, and yielding up to 240 tracking days based on battery life (Mosquera-Guerra et al. 2021).

Locations were classified by the ARGOS system into one of six location classes (LCs). Based on the level of accuracy measured in kilometers of uncertainty for latitude and longitude. ARGOS classifies location quality relative to an estimated error radius in the following location classes: 3 (accurate to $<250 \mathrm{~m}$ ), 2 (accurate to 250-500 m), 1 (accurate to 500-1500 m), and A and B (1-2 messages received but no accuracy estimation). In our study, we used only the most accurate data, LCs 3 and 2, after filtering the data with SAS-routine and ARGOS-Filter (Witt et al. 2010; Wells et al. 2017; Dolton et al. 2020; MosqueraGuerra et al. 2021). Data with low accuracy, LC1 (500-1500 m), and data in classes A and B, with no accuracy estimations, were not used in our analysis.

Habitat type spatial classifications

A set of satellite images of the study areas during the periods of satellite monitoring of Amazon River dolphins were downloaded from the USGS (The United States Geological Survey) platform and provided by the Landsat 8 satellite (USGS 2021). The satellite images used had cloudiness that was lower than $30 \%$ and had sufficient resolution for the identification of the different types of habitats used by river dolphins, such as (1) main river, (2) confluences, (3) tributaries, (4) channels, (5) islands, (6) bays, and (7) lagoons, as proposed by Gómez-Salazar et al. (2011a); see Table 1). The satellite images were processed using ArcGIS 10.8.1 software; and two combinations were selected to exhibit the spatial dynamics of the river stretches evaluated, such as ( 1 ) natural color with the combination of bands 4 (red 0.636-0.673 $\mu \mathrm{m}$ ), 3 (green 0.533-0.590 $\mu \mathrm{m}$ ), 2 (blue 0.452-0.512 $\mu \mathrm{m}$ ), and (2) land use/watercourses with bands 5

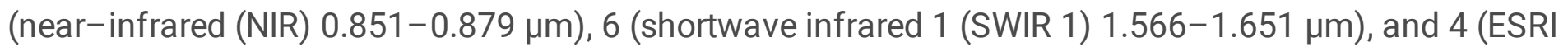
2021). Subsequent locations of monitored Amazon River dolphins in each of the classified habitat types 
were spatialized and quantified through the processing of satellite images for each of the study areas using ArcGIS 10.8.1 software (ESRI 2021; see Fig. 2).

Table 1

Definitions of hábitat types, included those in Martin and Da Silva (2004a); Gómez Salazar et al. (2011a); and Aliaga-Rossel and Guisada-Durán (2020)

\begin{tabular}{|c|c|c|}
\hline Habitat type & Definition & Locations surveyed \\
\hline Main river & $\begin{array}{l}\text { Whitewater rivers of Andean and } \\
\text { Guianan shield origin, typically turbid, } \\
\text { brown-yellow in color with low } \\
\text { transparency, basic pH, and sediment- } \\
\text { rich (Sioli 1984). At least } 400 \text { m in } \\
\text { width. }\end{array}$ & Amazonas and Orinoco rivers. \\
\hline Confluences & $\begin{array}{l}\text { Intersection areas of the main channel } \\
\text { with other channels or rivers. } \\
\text { Confluences maintain connections } \\
\text { during all hydrologic seasons and may } \\
\text { or may not show a mix of white and } \\
\text { blackwaters. Approximately } 250 \mathrm{~m} \\
\text { width. }\end{array}$ & $\begin{array}{l}\text { Confluences between the Amazonas River } \\
\text { - Atacuari and Loretoyacu rivers. Orinoco } \\
\text { River - Guaviare, Bita, and Meta rivers. } \\
\text { Guayabero River - Yarumales Creek, and } \\
\text { Guaviare and Inírida rivers. }\end{array}$ \\
\hline Tributaries & $\begin{array}{l}\text { Small and medium size rivers no more } \\
\text { than } 400 \text { m in width. Water in tributaries } \\
\text { is usually black and clear, originate } \\
\text { from the flooded forest plains with few } \\
\text { suspended sediments and relatively } \\
\text { acidic, high in tannins and particulate } \\
\text { organic matter (Sioli 1984). }\end{array}$ & $\begin{array}{l}\text { Loretoyacu, Atacuari, and Amacayacú in } \\
\text { the Amazon basin; Arauca, Meta, Bita, } \\
\text { Guayabero, Guaviare, Inírida rivers in the } \\
\text { Orinoco basin. }\end{array}$ \\
\hline Channels & $\begin{array}{l}\text { Watercourses not exceding } 300 \text { m wide } \\
\text { and generally associated with island } \\
\text { and main river systems. Navigability is } \\
\text { limited depending on the rainy seasons. }\end{array}$ & $\begin{array}{l}\text { Channels from Amazonas River to the } \\
\text { Caballo Cocha Lake, between the El } \\
\text { Correo and Tarapoto lakes, and Cacao } \\
\text { Island. Channels from Orinoco River } \\
\text { beteween the confluence with the Bita } \\
\text { River to the Ventanas Rapids, and finally } \\
\text { from the Guaviare River to Carbon Creek. }\end{array}$ \\
\hline Islands & $\begin{array}{l}\text { Waters around land bodies in the } \\
\text { watercourse of main rivers with } \\
\text { vegetation that may appear or } \\
\text { disappear due to hydrologic dynamics. }\end{array}$ & $\begin{array}{l}\text { Bugeo, Cacao, Mocagua, Patrullero, San } \\
\text { Salvador, and Vamos Islands in the } \\
\text { Amazonas River. El Pañuelo and Ventanas } \\
\text { in the Orinoco River. }\end{array}$ \\
\hline Bays & $\begin{array}{l}\text { Meanders or curves along the main river } \\
\text { course with longer water retention times } \\
\text { than the main channel and lower } \\
\text { current velocity. }\end{array}$ & $\begin{array}{l}\text { All sections in the assessed rivers had } \\
\text { bays. }\end{array}$ \\
\hline
\end{tabular}

Home range and hotspot activity

We estimated the home range and core areas were calculated for monitored individuals using the kernel density estimate (KDE) tool of the spatial analyst tool extension in ArcMap 10.8.1 at 95\% exceedance value (Seaman and Powell 1996; Kernohan et al. 2001; Powell and Michell 2012; Mosquera-Guerra et al. 
2021; Sevigny et al. 2021). We also estimated core use areas at a $50 \%\left(K_{50}\right)$ isopleth to identify the most frequently used spaces within each HR (Mosquera-Guerra et al. 2021; Sevigny et al. 2021). We regard this analysis as the hotspot of Amazon River dolphin activity in the areas assessed. Mapping was performed using the geostatistical analyst and spatial analyst extensions in ESRI ArcGIS version 10.8.1. (ESRI 2021). The smoothing parameter of the Beizer interpolation was used following Wells et al. (2017); Dolton et al. (2020), and Mosquera-Guerra et al. (2021).

\section{Statistical analysis}

We used generalized additive models for location, scale, and shape (GAMLSS) following Cruz et al. (2018) to understand the relationship between the number of locations per habitat type with the predictor variables: (1) body length ( $\mathrm{cm}),(2)$ body mass $(\mathrm{kg}),(3) \operatorname{sex}(F=$ female, $M=$ male), (4) tracking duration (days), (5) habitat type, (6) $\mathrm{K}_{95}\left(\mathrm{~km}^{2}\right),(7) \mathrm{K}_{50}\left(\mathrm{~km}^{2}\right)$, (8) longest distance between locations $(\mathrm{km})$, and (9) elevation (m.a.s.l.).

The GAMLSS approach is a semi-parametric method that allows exploring the relationship between the predictor variables and the response variables to be modeled either parametrically with linear or nonlinear predictors or non-parametrically with smooth nonparametric terms (e.g., cubic splines or loess) and random effects (Rigby \& Stasinopoulos 2010; Cruz et al. 2018). GAMLSS can be considered as an extension of GAMs and generalized linear models. This method allows a wide range of skewed and kurtotic distributions by explicitly modelling various distributional parameters that might include the location/mean, scale/dispersion, skewness, and kurtosis as functions of predictor variables (Rigby \& Stasinopoulos 2005; Cruz et al. 2018). Generalized additive models for location, scale, and shape with a zero-adjusted gamma distribution (ZAGA) and zero-inflated beta distribution (BEZI) were used to model a continuous response and to deal with the excess of zeros. Models were ranked using the generalized Akaike information criterion (GAIC; Burnham \& Anderson 2002). We found negative binomial distributions to be the best distribution family to describe our response variable adequately.

These models were developed using the gamlss package (Stasinopoulos \& Rigby 2007) with the software R.4.0.3 (R Core Team 2020) for the graphical representation using the R software package ggplot2. In all cases, a value of $p<0.05$ was considered statistically significant.

\section{Results}

Location data

Our satellite monitoring of the 17 Amazon River dolphins reported 16.098 locations (Amazonas River, $\mathrm{n}=$ 2.934 locations, and Orinoco basin, $n=13.164$ locations) that were subsequently associeted with the seven habitat types identified in the evalueted transects (see Table S1, Fig. 3a-f). Locations of the 17

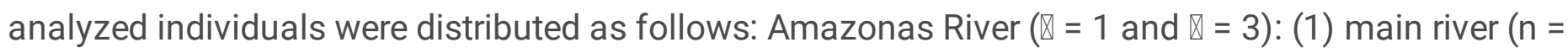
$1.346,46 \%) ;(2)$ confluences $(n=177,6 \%)$; (3) tributaries $(n=43,1 \%) ;(4)$ channels $(n=62,2 \%) ;(5)$ 
islands $(n=131,4 \%) ;(6)$ bays $(n=17,1 \%)$; and $(7)$ lagoons $(n=1.158,39 \%)$ and Orinoco basins $(\mathbb{B}=7$ and $\mathbb{Q}=6)$ : (1) main river $(n=7.798,59.2 \%)$; (2) confluences $(n=755 ; 5.7 \%)$; (3) tributaries $(n=1.380$; $10.5 \%)$; (4) channels $(n=1.535 ; 11.7 \%) ;(5)$ islands $(n=607,4.6 \%) ;(6)$ bays $(n=1.079,8.2 \%)$; and $(7)$ lagoons $(n=10,0.1 \%)$; see Table 2, Fig. 4$)$.

Table 2

Range (mean \pm SE) of the number of locations reported by satellite-monitored I. geoffrensis individuals and classified into the different habitat types evaluated for the Amazonas River and Orinoco basin

\begin{tabular}{|c|c|c|}
\hline \multirow[t]{2}{*}{ Habitat types } & Amazonas River & Orinoco basin \\
\hline & Range (mean \pm SE) & Range (mean $\pm S E$ ) \\
\hline Main River & $143-614$ locations (mean $=336 \pm 232$ ). & $4-4.388$ locations $($ mean $=600 \pm 1.216$ \\
\hline Confluences & $8-74$ locations (mean $=44 \pm 30)$. & $104-651$ locations (mean $=58 \pm 180)$. \\
\hline Tributaries & $7-23$ locations $($ mean $=11 \pm 10)$ & $22-881$ locations (mean $=106 \pm 267$ ). \\
\hline Channels & $7-32$ locations $($ mean $=15 \pm 15)$ & $2-561$ locations $($ mean $=118 \pm 189)$. \\
\hline Islands & 38-93 locations (mean $=33 \pm 44$ ). & $4-271$ locations (mean $=47 \pm 86$ ). \\
\hline
\end{tabular}

Bays $\quad 5-7$ locations (mean $4 \pm 3$ ). $\quad 1-423$ locations (mean $83 \pm 116$ ).

Lagoons $\quad 3-1.028$ locations $($ mean $=289 \pm 493) . \quad 2-4$ locations $($ mean $=1 \pm 1.5)$.

Habitat type spatial classifications

Proportions of the number of locations reported for I. geoffrensis individuals monitored in the Amazonas River and the Orinoco basin were classified into the seven habitat types evaluated (see Fig. 5). The habitat type with the highest frequency for individuals monitored in the Amazonas River was the main river, followed by lagoons, confluences, channels; and only half of the individuals used the islands and bays (see Fig. 5). In the Orinoco basin all individuals occupied the main river followed by canals, bays, islands, tributaries; and confluences were used by individuals (GVE $181016 \mathrm{~F}$ and GYO $181013 \mathrm{M}$ ), and lagoons by (BI 181017 F and GVE 181016 F; see Fig. 5).

The best-fitting GAMLSS for the I. geoffrensis monitored individuals in the Amazonas River showed that body length, sex, and habitat types (lagoons and main river) were significant predictors of Amazon River dolphin habitat use (see Tables 3 and 4). The model predicted that habitat use of river dolphins depends on the body length and sex of the individuals and the specific use of habitat types such as lagoons and the main river (see Fig. 6a-c). 
Table 3

GAMLSS models for the I. geoffrensis monitored individuals in the Amazonas River with $\mathrm{df}$ (degree of freedom) and GAIC for the response variable number locations per habitat types and explanatory predictors as follow: (1) body length (cm), (2) body mass (kg), (3) sex (F: female and M: male), (4) tracking duration (days), (5) habitat types, (6) $\mathrm{K}_{95}\left(\mathrm{~km}^{2}\right)$, (7) $\mathrm{K}_{50}\left(\mathrm{~km}^{2}\right)$, (8) longest distance between locations $(\mathrm{km})$, and (9) elevation (m.a.s.l.)

\section{Model Model df GAIC \\ ID}

$1 \quad$ Number of locations per habitat types body length $(\mathrm{cm})+\operatorname{sex}(\mathrm{F}$ and $\mathrm{M})+11274.42$ habitat types

$2 \quad$ Number of locations per habitat types $\sim$ body length $(\mathrm{cm})+$ body mass $(\mathrm{kg})$ $+\operatorname{sex}(\mathrm{F}$ and $\mathrm{M})+$ longest distance $(\mathrm{km})+$ tracking duration (days) + habitat types $+\mathrm{K}_{50}\left(\mathrm{~km}^{2}\right)+$ elevation (m.a.s.l.)

Number of locations per habitat types $\sim$ body length $(\mathrm{cm})+$ body mass $(\mathrm{kg})$ $16 \quad 276.03$ $+\operatorname{sex}(\mathrm{F}$ and $\mathrm{M})+$ tracking duration (days) + habitat types $+\mathrm{K}_{95}\left(\mathrm{~km}^{2}\right)+\mathrm{K}_{50}$ $\left(\mathrm{km}^{2}\right)+$ longest distance $(\mathrm{km})+$ elevation (m.a.s.I.)

Table 4

Summary of predictor estimates from the best-fitting GAMLSS predicting the habitat use by the I. geoffrensis monitored individuals in the Amazonas River, including as follow: estimate, standard error, $t$ and $p$ values

Explanatory $\quad$ Estimate Standard Error $t \quad p$ predictors

\begin{tabular}{lllll}
\hline Intercept & -68.66 & 17.26 & -3.97 & $0.00097^{*}$ \\
\hline Body length $(\mathrm{cm})$ & 0.35 & 0.08 & 4.13 & $0.0006^{*}$ \\
\hline Sex $(\mathrm{F}$ and $\mathrm{M})$ & 7.39 & 2.03 & 3.64 & $0.002^{*}$ \\
\hline Channels & 1.01 & 1.25 & 0.8 & 0.43 \\
\hline Confluences & 2.32 & 1.4 & 1.65 & 0.11 \\
\hline Island & 1.6 & 2.34 & 0.6 & 0.5 \\
\hline Lagoons & 3.58 & 1.56 & 2.29 & $0.03^{*}$ \\
\hline Main river & 4.36 & 1.88 & 2.31 & $0.03^{\star}$ \\
\hline Tributaries & 0.72 & 1.23 & 0.6 & 0.56
\end{tabular}

Note: Those significant for the explanatory predictors are marked with an asterisk $\left({ }^{*}\right)$.

The best-fitting GAMLSS for the I. geoffrensis monitored individuals in the Orinoco basin showed that body length, longest distance, $\mathrm{K}_{50}$, and habitat type (confluences, lagoons, main river, and tributaries) were significant predictors of Amazon River dolphin habitat uses (see Tables 5 and 6). The model predicted that habitat use of river dolphins depends on the longest distance and core area $\left(\mathrm{K}_{50}\right)$ of the 
individuals as well as the specific use of habitat types such as confluences, lagoons, main river, and tributaries (see Fig. 7a-c).

Table 5

GAMLSS models for the I. geoffrensis monitored individuals in the Orinoco basins with df (degree of freedom) and GAIC for the response variable numbered locations per habitat types and explanatory predictors as follow: (1) body length (cm), (2) body mass (kg), (3) sex (F: female and M: male), (4) tracking duration (days), (5) habitat types, (6) $\mathrm{K}_{95}\left(\mathrm{~km}^{2}\right)$, (7) $\mathrm{K}_{50}\left(\mathrm{~km}^{2}\right)$, (8) longest distance between locations $(\mathrm{km})$, and (9) elevation (m.a.s.l.)

\section{Model Model df GAIC \\ ID}

$1 \quad$ Number of locations per habitat types $\sim$ body length $(\mathrm{cm})+$ habitat types + $\mathrm{K}_{50}\left(\mathrm{~km}^{2}\right)+$ longest distance $(\mathrm{km})$

$12 \quad 694.98$

Number of locations per habitat types $\sim$ body length $(\mathrm{cm})+$ body mass $(\mathrm{kg}) \quad 14 \quad 696.94$

+ habitat types $+\mathrm{K}_{50}\left(\mathrm{~km}^{2}\right)+$ longest distance $(\mathrm{km})+$ elevation (m.a.s.I.)

$3 \quad$ Number of locations per habitat types body length $(\mathrm{cm})+$ body mass $(\mathrm{kg}) \quad 16 \quad 700.98$

$+\operatorname{sex}(\mathrm{F}:$ female and M: male) + tracking duration (days) + habitat types+

$\mathrm{K}_{50}\left(\mathrm{~km}^{2}\right)+$ longest distance $(\mathrm{km})+$ elevation (m.a.s.I.)

Table 6

Summary of predictor estimates from the best-fitting GAMLSS predicting the habitat use by the I. geoffrensis monitored individuals in the Orinoco basins, including the following: estimate, standard error, $t$ and $p$ values

\begin{tabular}{lllll}
$\begin{array}{l}\text { Explanatory } \\
\text { predictors }\end{array}$ & Estimate & Standard Error & $t$ & $p$ \\
\hline Intercept & 1.90 & 1.66 & 1.14 & 0.25 \\
\hline Body length $(\mathrm{cm})$ & 0.01 & 0.008 & 1.85 & 0.06 \\
\hline Longest distance $(\mathrm{km})$ & 0.01 & 0.003 & 3.88 & $0.0002^{*}$ \\
\hline $\mathrm{K}_{50}\left(\mathrm{~km}^{2}\right)$ & -0.45 & 0.14 & -3.23 & $0.001^{*}$ \\
\hline Channels & 0.11 & 0.53 & 0.21 & 0.82 \\
\hline Confluences & -2.56 & 0.80 & -3.16 & $0.002^{*}$ \\
\hline Island & -1.11 & 0.61 & -1.81 & 0.07 \\
\hline Lagoons & -3.5 & 1.20 & -2.9 & $0.004^{\star}$ \\
\hline Main river & 1.08 & 0.49 & 2.19 & $0.03^{*}$ \\
\hline Tributaries & -1.53 & 0.67 & -2.27 & $0.02^{*}$
\end{tabular}

Note: Those significant for the explanatory predictors are marked with an asterisk $(*)$. 
Home range and hotspot activity

Home range size $\left(\mathrm{K}_{95}\right)$ for the four $(\mathbb{\nabla}=1 ; \nabla=3)$ I. geoffrensis individuals monitored in the section evaluated in the Amazonas River ranged from 30.7-105.5 km² (mean = $62 \pm 32$ ), and the largest core areas $\left(\mathrm{K}_{50}\right)$ or hotspots of activity were recorded in the main river, confluences, lagoons, and tributaries (see Table 7). In five rivers of the Orinoco basin, 13 monitored individuals $(\nabla=7 ; \nabla=6)$ registered $\mathrm{K}_{95}: 6^{-}$ $116 \mathrm{~km}^{2}$ (mean $\left.=32.8 \pm 31.53\right)$, and the largest core areas $\left(\mathrm{K}_{50}\right)$ or hotspots of activity were recorded in the main river, islands, channels, confluences, bays, tributaries, and lagoons (see Table 7).

Table 7 Range (mean \pm SE) of the size of hotspots of Amazon River dolphin activity or core area $\left(K_{50}\right)$ reported by satellite-monitored I. geoffrensis individuals and classified in the different habitat types evaluated for the Amazonas River and Orinoco basin

\begin{tabular}{|c|c|c|}
\hline Habitat types & $\begin{array}{c}\text { Amazonas River } \\
\mathbf{K}_{50}\left(\mathbf{k m}^{2}\right) \\
\end{array}$ & $\begin{array}{c}\text { Orinoco basin } \\
\mathbf{K}_{50}\left(\mathrm{~km}^{2}\right)\end{array}$ \\
\hline Main River & $1.3-3.6 \mathrm{~km}^{2}($ mean $=2.2 \pm 1.2)$ & $0.4-5.5 \mathrm{~km}^{2}($ mean $=2.3 \pm 2)$ \\
\hline Confluences & $1-2.9 \mathrm{~km}^{2}($ mean $=1.9 \pm 1.3)$ & $0.2-0.9 \mathrm{~km}^{2}($ mean $=0.5 \pm 0.4)$ \\
\hline Tributaries & $0.03 \mathrm{~km}^{2}$ & $0.01-0.5 \mathrm{~km}^{2}($ mean $=0.1 \pm 0.2)$ \\
\hline Channels & & $0.005-2.3 \mathrm{~km}^{2}($ mean $=0.7 \pm 0.9)$. \\
\hline Islands & & $0.02-5 \mathrm{~km}^{2}($ mean $=1.4 \pm 1.7)$ \\
\hline Bays & & $0.005-1.9 \mathrm{~km}^{2}($ mean $=0.4 \pm 0.6)$ \\
\hline Lagoons & $0.11-1.24 \mathrm{~km}^{2}($ mean $=0.5 \pm 0.6)$ & $0.02 \mathrm{~km}^{2}$ \\
\hline
\end{tabular}

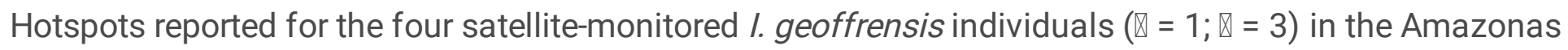
River corresponded for the female (AM $40679 \mathrm{~F}$ ) with the wetland complex of the Tarapoto lakes. Male (both AM $181675 \mathrm{M}$ and $\mathrm{AM} 181676 \mathrm{M}$ ) areas of intense use were associated with the main river and male (AM 40691-1 M) to the confluences between the Loretoyacu and the Amazonas rivers (see Fig. 8a).

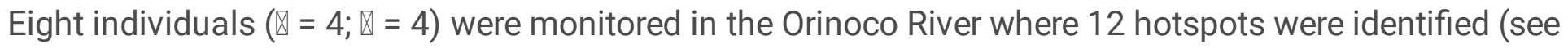
Fig. 8b); seven individuals (OR 40641 F; OR 171927 M; OR 181019 F; OR 40691 F; OR 181015 M; OR $40688 \mathrm{M}$, and OR $181019 \mathrm{~F}$ ) were associated with the main river between the confluence Meta-Orinoco rivers, passing through Negro and El Pañuelo creeks, up to the Ventanas Rapids. Two individuals (OR 171927 M and OR 201339 M) were associated with the habitat type bay. Individual (OR 17927 M) had a core area in the Bita River, a tributary of the Orinoco River, and individuals (OR $181019 \mathrm{~F}$ and OR 181020 F) had hotspots associated with the channels formed by El Pañuelo Island and the banks of the Orinoco River in the vicinity of the Bojonawi Nature Reserve and the other upstream of the Ventanas Rapids. Arauca River monitored a female of I. geoffrensis (AR 181018 F) and her two central areas of use were associated with the main river in the vicinity of the border city of Arauca (see Fig. 8c). In the Bita River the female (BI 181017 F) had a hotspot in the Orinoco River in the vicinity of the Bojonawi Nature Reserve (see Fig. 8d). In the Guayabero River, two males were monitored (see Fig. 8e) and one individual (GYO 
$40641 \mathrm{M}$ ) had two core areas on the main river, and an individual (GYO $181013 \mathrm{M}$ ) had two hotspots in the confluence of the habitat type between Guayabero River with the Yarumales and Claro creeks and Guaviare River. The female (GVE 181016 F) had a hotspot in the tributary in the vicinity of the confluence between the Guaviare and Inirida rivers (see Fig. 8f).

\section{Discussion}

Habitat type spatial classifications

Understanding the influence of environmental heterogeneity on large mammal movements is critical for conservation (Newak and Richart 2012). Dispersal and migration of river mammals such as dolphins, manatees, and otters implies, for these types of organisms, the challenge of facing constrasting environmental conditions along the river courses (Sawyer et al. 2009; Sawyer and Kauffman 2011) and converting the environmental heterogeneity into a crucial aspect for understanding the animals' spatial ecology (Newak and Rickart 2012). The environmental heterogeneity of rivers, not only refers to the variability of river segments in terms of their physical and biological conditions, but also the fact that river landscapes can change drastically in time according to flood pulses. Plants and animals have adapted their behavior and reproductive cycles to the constant fluctuation of their niche. The instability of river habitats has selected for not only high vagility among riverine species (migrating patterns), but also it has selected a top predator, Amazon River Dolphins, for adaptations for the opportunistic use of a changing environment (adaptated to habitat heterogeneity). All Amazon River fish species show either lateral or longitudinal migratory patterns dictated by flood pulses (Zapata and Usma 2013; Barthem et al. 2017). More than 15 million years of evolution in Neotropical aquatic ecosystems (Geisler et al. 2011), have selected in I. geoffresis a set of adaptations for foraging along fluctuating and constrasting habitats. Compared with other cetateans, Amazon River dolphins have increased their maneuverability across different types of aquatic landscapes (unfused cervical vertebrae, large, broad, paddle-like flippers, da Silva and Martin 2014), and are the only cetacean exhibiting both, conical and molar-like teeth, expanding the spectrum of their fish prey size (25-90 cm, da Silva 1983; Best and da Silva 1989).

The intensity of use of different habitat types by I. geoffrensis is primarily influenced by (1) the abundance and availability of fish prey, (2) the accessibility to foraging locations, determined mainly by the flooding pulse and river geomorphology, and (3) the sexual and reproductive conditions of the individuals in a group (McGuire and Winemiller 1998; Martin and da Silva 1998; Trujillo 2000; Martin and da Silva 2004; McGuire and Henningsen 2007; Yamamoto et al. 2015; Mintzer et al. 2016; MosqueraGuerra et al. 2021). Amazon River dolphins make up one of the smallest group sizes among odontocetes as a strategy to increase individual fitness, and reduce competition for prey during declines in fish abundance during the high water period (Gómez et al. 2011a). This species shows sexual segregation in habitat use (Mintzer et al. 2016), similar to other species of odontocete species (e.g., Beluga whale [Delphinapterus leucas, Loseto et al. 2006], northern bottlenose whales [Hyperoodon ampullatus, Gowans et al. 2001], and sperm whales [Physeter microcephalus, Whitehead and Weilgard 2000]). 
Our results show strong sexual segregation for habitat use among satellite-monitored individuals in the Amazonas River. The documented differential behaviors in the intensity of habitat use between males and females coincide with observations made by Trujillo (2000) in the lakes of Tarapoto and the Colombian Amazonas and Martin and da Silva $(1998 ; 2004)$ who analyzed data from 24 individuals monitored with radio telemetry in the Mamiraua Sustainable Development Reserve. They report that during the period of rising water adult females and calves use lagoons, floodplain and channels more intensively due to factors such as distribution patterns and abundance of small prey (gymnotids, cichlids, and catfish) associated with floating vegetation (Crampton 1999; Martin and da Silva 2004a). This allows them to meet the energetic requirements of the young as well as providing safety for mothers and young from male harassment (Martin and da Silva 2004a; Yamamoto et al. 2015). Lagoons and channels are characterized by slow river flow, necessitating lower energy expenditure in these habitats (Aliaga and Guizada 2020; Martin and da Silva 2004). Males use the main river and confluences due to the presence of large schools of characins that make breeding migrations or move between habitat types due to changes in dissolved oxygen concentration levels in the water at night (da Silva 1983; Martin and da Silva 1998; Crampton 1999; Martin and da Silva 2004a, Yamamoto et al. 2015; Mintzer et al. 2016).

In the case of individuals monitored in the five rivers of the Orinoco basin sexual segregation by habitat type was not as evident as that reported for groups analyzed in the Amazon basin. A not very evident habitat sexual segregation behavior in the Orinoco basin has been also reported by McGuire and Winemiller (1998) for the Cinaruco River in Venezuela, and McGuire and Aliaga-Rossel (2007). They compared reproductive patterns in the Orinoco, Amazonas, and Mamoré rivers and suggested that habitat selection by I. geoffrensis in the Orinoco basin is influenced by strong seasonality of this aquatic system and its effects on the fluctuations of local fish populations. Habitat availability and habitat extension related to flood plains and lagoons that are frequently associated with female parental care in $I$. geoffrensis at the Amazon are significantly reduced in the Orinoco basin due to geomorphological determinants (Mosquera-Guerra et al. 2021). Time of water retention is low and flow velocity is high in the Orinoco basin when compared with the Amazon basin; and this compromises the formation of meanders and lagoons that are ideal for female parental care (McGuire and Winemiller 1998) and explain the reduction of habitat segregation between males and females. Apparently, females in the Orinoco are adapted to the above-described situation using the main river channel, and tributaries for nursing. In addition, McGuire and Aliaga-Rossel (2007a) propose a geographical variation in reproductive seasonality influenced by the effects of latitude on the water level flow and prey abundance. Reinforcing these ideas, Mintzer et al. (2016) reported that males and non-lactating females more frequently use the main river, the confluences, and the channels, and uses the lakes with lower intensity in the Japurá River in the Brazilian Amazon basin.

Mintzer et al. (2016) report that habitat use mediated by sexual segregation may influence the levels of risk to different types of human threats for river dolphins. Males and non-lactating females that intensively use the main river and channels are more likely to be exposed to collision by boats and negative interactions with fisheries, while females with calves in lakes and bays are more likely to suffer entanglements in monofilament nets used by fisherman in this type of habitat. In addition, these 
researchers highlight the intense use of the Amazon River dolphins of different habitat types within the Mamiraua Sustainable Development Reserve demonstrating the importance of the protected areas for $I$. geoffrensis populations in the Amazon basin.

Home range and hotspot activity

Home range size is the result of dynamic processes strongly influenced by both, large scale factors (hydroclimatic cycles and geomorphology) and fine-scale determinants (spatio-temporal distribution of important resources). In addition, besides changes in habitat availability the condition of the individuals (sex and state of development) determines habitat preferences, affecting home range size (Börger et al. 2008; Van Beest et al. 2011; Viana et al. 2018). Seasonal variation of home range in dolphins is determined by changes in habitat selection (Van Beest et al. 2011; Viana et al. 2018) associated with mating and rutting seasons (e.g., Dahle and Swenson 2003; Viana et al. 2018; Mosquera-Guerra et al. 2021).

Our mean home range value for monitored I. geoffrensis individuals in the Amazon River was higher than previously reported values and lower than home range values for individuals monitored in the Orinoco River in the same study (Mosquera-Guerra et al. 2021). Generalized additive models for location, scale, and shape (GAMLSS) have been used to evaluate the best ecological predictors that explain the home range size of Amazon River dolphins: (1) body mass and length (e.g., Buskirk 2004; Tucker et al. 2014; Kelt and Van Vuren 2001); (2) longest distance between locations (e.g., Trujillo 1994; 2000; Martin and da Silva 1998; 2004; 2004a; McGuire and Henningsen 2007; Denkinger 2010; Mintzer et al. 2016; MosqueraGuerra et al. 2021), and (3) sex and reproductive status (e.g., Martin and da Silva 2006; da Silva and Martin 2014; Martin and da Silva 2018).

Ecological hotspot definitions are typically related to location abundance and require a threshold to be applied to differentiate hot and non-hot locations (Stahl et al. 2001; Nelson and Boots 2008). Hotspots are spatially explicit and can be detected at particular geographic locations (Chulick et al. 2002; Nelson and Boots 2008). Hotspot activity reported in this study for the individuals of I. geoffrensis monitored in the Amazonas River are associated with the following habitat types: (1) main river, (2) confluences, (3) tributaries, and (4) lagoons. The intense use of these habitat types by the Amazon River dolphins coincides with previously reported fidelity sites for the Amazonian rivers as follow: (1) Cuyabeno and Lagartococha in Ecuador (e.g., Denkinger 2010), (2) Marañon in Peru (e.g., McGuire and Henningsen 2007), (3) Tijamuchi and Mamoré in Bolivia (e.g., Aliaga-Rossel 2002; Aliaga-Rossel and Guizada-Durán 2020), (4) Amazonas in Colombia (e.g., Trujillo 2000; Gómez-Salazar et al. 2011a), and (5) Japurá and Solimoes in Brazil (e.g., Martin \& Da Silva 2004; 2004a; Yamamoto et al. 2015; Mintzer et al. 2016). In the rivers of the Orinoco basin, hotspot activity was associated with the following: (1) main river, (2) confluences, (3) tributaries, (4) channels, (5) bays, and (6) lagoons. They coincide with those reported for the rivers: (1) Cinaruco in Venezuela (e.g., McGuire and Winemiller 1998), and (2) the Orinoco in Colombia (e.g., Trujillo 2000; Gómez-Salazar et al. 2011a). 
Hot spot activity size may be explained by the fact, that some individuals may remain residents in relatively small areas (Bjørge 2002). Although these individuals generally have well-defined home ranges, their distribution and the use of space within these home ranges refers to individual movements rather than to an entire population (Morales et al. 2004; 2010). This is particularly true in fission-fusion societies, such as those seen in many cetacean species including Amazon River dolphins (Gómez et al. 2011; Gravena et al. 2019), where individuals within the same population may have significantly different ranging patterns (Defran et al. 1999) and individuals may alternate between local site-fidelity and longer ventures away from the site of their first identification (Sprogis et al. 2015; Rako-Gospić et al. 2017; Mosquera-Guerra et al. 2021).

Hotspot activity of I. geoffrensis in the Amazonas River is located within the wetlands of international importance or Ramsar sites: Tarapoto Lakes Complex and in the Orinoco basin, hotspots identified in the Guayabero River in the aquatic ecosystems of the National Natural Parks Serranía de La Macarena and Tinigua, and the area of ecological importance for the species designated by the environmental corporation Cormacarena at the confluence between the Yarumales stream and the Guayabero River, the Guaviare River in the Estrella Fluvial de Inírida Ramsar site, the Orinoco basin in the Bita River Ramsar site, and the El Tuparro Biosphere Reserve. Our results demonstrate the importance of spatial ecology analysis of endangered wildlife by the definition of protected areas, quantifying the use of ecosystems within these areas, and the location of priority areas for the implementation of management measures for these species and habitats (Reyers et al. 2009; Zhang and Fu 2014).

\section{Conclusions}

This study demonstrated the usefulness of special ecological analyses in determining the intensity of habitat use, home range, and the identification of hotspots of Amazon River dolphin activity. This information contributes in a relevant way to the construction of conservation strategies for the species and its habitats, such as the designation of three wetlands of international importance or Ramsar sites in Colombia: (1) Tarapoto wetland complex in the Amazonas River, (2) Estrella Fluvial de Inirida, and (3) Bita River in the Orinoquia. Additionally, I. geoffrensis as an ecological indicator of freshwater ecosystems was prioritized in the management plans of Ramsar sites through actions such as conservation agreements for sustainable fishing with local communities and responsible observation programs for these cetaceans.

We highlight the influence of the sexual condition of the monitored individuals, ecological dynamics of prey such as abundance and movements, and the flood pulse on the intensity of use of the different habitats occupied by Amazon River dolphins. We also underline the vulnerability of I. geoffrensis to drives such as (1) the regulation of the flood pulses by climatic variability events or the construction of hydroelectric dams in the upper parts of the watersheds hindering river dolphin access to lagoons and tributaries during the low water period and reducing the extent of floodplains during the high water period; (2) sedimentation of channels, bays, and tributaries resulting from altered fluvial geomorphology due to bank erosion; and (3) decreased levels of prey biomass because of overfishing and deforestation of the 
flooded forest. Special ecological analyses contribute to the management and conservation of populations of endangered small cetaceans such as the Amazon River dolphin through the identification of areas of intense use and the delimitation of protected areas in the face of current scenarios for this group that are represented by the extinction of the baiji or Yangtzé River dolphin (Lipotes vexillifer) Turvey et al. 2007), and the critical status of the vaquita (Phocoena sinus) Aragon-Noriega et al. 2010; JaramilloLegorreta et al. 2017).

\section{Declarations}

Acknowledgements This program is part of the strategic plan defined by the South American River Dolphin Initiative (SARDI) supported by the World Wildlife Fund (WWF) in Brazil, Colombia, Perú, Ecuador, and Bolivia. FMG received a Postdoctoral Fellowship from Pontificia Universidad Javeriana (ID project: 20389 to 2021). We acknowledge the Whitley Fund For Nature, CORMACARENA, CORPORINOQUIA, CORPOAMAZONIA, Projects Design and Development (PDD), the fishing communities, and the local and national authorities for participating in the Amazon River dolphin capture process.

Author contributions FMG, FT, DAP, HMM and JPT conceived the study. FMG, FT, DAP, HMM, JPT and NFL designed the methodology. FT acquired the data, and FMG, JPT, NFL, DAP, HMM, JSUO, MJV, EAL and PTF and interpreted the results. FMG wrote the first draft of the paper, and all the authors contributed to its writing.

Funding This work was funded by the Fundación Omacha and Postdoctoral Fellowship from Pontificia Universidad Javeriana (ID project: 20389 to 2021).

Data availability All data generated or analyzed in this study are included in this published article and its supplementary information files.

Code availability Not applicable.

Conflict of interest The authors declare that there is no conflict of interest regarding the publication of this article.

Ethical approval Not applicable.

Consent to participate Not applicable.

Consent to publication Not applicable.

\section{References}

1. Ager AA, Johnson BK, Kern JW, Kie JG (2003) Daily and seasonal movements and habitat use by female rocky mountain elk and mule deer. J Mammal 3:1076-1088 
2. Aliaga-Rossel E (2002) Distribution and abundance of the pink river dolphin, bufeo (Inia geoffrensis) in the Tijamuchi River, Beni-Bolivia. Aquat Mamm 28:312-323

3. Aliaga-Rossel E, Guizada-Durán LA (2020) Bolivian river dolphin site preference in the middle-section of Mamoré River, upper Madeira river basin, Bolivia. Theyra 11:459-465

4. Anderson EP, Osborne T, Maldonado-Ocampo JA, Mills-Novoa M, Castello L, Montoya M, Encalada AC, Jenkins CN (2019). Energy development reveals blind spots for ecosystem conservation in the Amazon Basin. Front Ecol Environ 17:521-529

5. Aragon-Noriega EA, Rodriguez-Quiroz G, Cisneros-Mata MA, Ortega-Rubio A (2010) Managing a protected marine area for the conservation of critically endangered vaquita (Phocoena sinus Norris, 1958) in the Upper Gulf of California. Int J Sust Dev World 17: 410-416

6. Banguera-Hinestroza E, Cárdenas H, Ruíz-García M, Marmontel M, Gaitán E, Vázquez R, GarciaVallejo F (2002) Molecular identification of evolutionarily significant units in the Amazon River dolphin Inia sp. (Cetacea: Iniidae). J Hered 93:312-322

7. Barthem RB, Goulding M, Leite RG, Cañas C, Forsberg B, Venticinque E, Petry P de B, Ribeiro ML, Chuctaya J, Mercado A (2017) Goliath catfish spawning in the far western Amazon confirmed by the distribution of mature adults, drifting larvae and migrating juveniles. Scient Report 7:41784

8. Berger J (2004) The last mile: how to sustain long-distance migration in mammals. Conserv Biol 18:320-331

9. Best RC, da Silva VMF (1989) Amazon River dolphin. boto Inia geoffrensis (de Blainville, 1817). In: Ridgway SH, Harrison R (eds) Handbook of marine mammals, River dolphins and the larger toothed whales, Academic Press, London, pp 1-24

10. Bjørge A (2002) How Persistent are Marine Mammal Habitats in an Ocean of Variability?. In: Evans PGH, Raga JA (eds) Marine Mammals, Springer, Boston, pp 63-91

11. Bolger DT, Newmark WD, Morrison TA, Doak DF (2008) The need for integrative approaches to understand and conserve migratory ungulates. Ecol Lett 11:63-77

12. Börger L, Dalziel BD, Fryxell JM (2008) Are there general mechanisms of animal home range behaviour? A review and prospects for future research. Ecol Lett 11:637-50

13. Brum S, Rosas-Ribeiro P, de Souza Amaral R, de Souza DA, Castello L, Ferreira da Silva VM (2021) Conservation of Amazonian aquatic mammals. Aquat Conserv: Mar Freshw Ecosyst 1:1-19

14. Burnham KP, Anderson DR (2002) Model selection and inference: a practical information-theoretic approach. Springer, NY

15. Buskirk S (2004) Keeping an Eye on the Neighbors. Science 306:238-239

16. Chetkiewicz CL, St Clair CC, Boyce MS (2006) Corridors for Conservation: integrating Pattern and Process. Ann Rev Ecol Evol Syst 37:317-342

17. Chulick GS, Mooney WD, Detweiler ST (2002) Crustal structure of North America and the adjacent ocean basins. Geol Soc Am 33:2478-2492 
18. Crampton WGR (1999) Os peixes da Reserva Mamirauá: Diversidade e historia natural na planície alagável da Amazonia. In: Queiroz HL, Crampton WGR (eds) Estrategias para manejo de recursos pesqueiros em Mamirauá, Sociedade civil Mamirauá/CNPq, Brasília, pp 10-36

19. Crooks KR, Sanjayan M (2006) Connectivity Conservation. Cambridge University Press, CB

20. Cruz MJ, Machete M, Menezes G, Rogan E, Silva MA (2018) Estimating common dolphin bycatch in the pole-and-line tuna fishery in the Azores. PeerJ: 1-18

21. Dahle B, Swenson JE (2003) Seasonal range size in relation to reproductive strategies in brown bears Ursus arctos. J Anim Ecol: 72:660-7

22. Da Silva VMF (1983) Ecologia alimentar dos golfinhos da Amazônia. Master of Science Thesis, Universidade do Amazonas

23. Da Silva VMF (2009) Amazon river dolphin (Inia geoffrensis). In: Perrin WF, Würsig B, Thewissen JGM (eds) Encyclopedia of Marine Mammals, Academic Press, London, pp 26-28

24. Da Silva VMF, Martin AR (2014) Family Iniidae (Amazon river dolphis). In: Wilson DE, Mittemeier RA (eds) Handbook of the Mammals of the Word, Lynx Edicions, Barcelona, pp 364-379

25. Da Silva V, Trujillo F, Martin A, Zerbini AN, Crespo E, Aliaga-Rossel E, Reeves R (2018) Inia geoffrensis Assessment. https://www.iucnredlist.org. Accessed 1 July 2021

26. Defran RH, Weller DW, Kelly DL, Espinosa MA (1999) Range characteristics of Pacific coast bottlenose dolphins (Tursiops truncatus) in the Southern California Bight. Marine Mammal Science 15:381-393

27. Denkinger J (2010) Population density, abundance estimates, habitat preference and social structure of Amazon river dolphins (Inia geoffrensis) in Cuyabeno Reserve, Ecuador. Av Cienc Ing 2:B91-B97

28. Di Bitetti MS (2001) Home range use by the tufted capuchin monkey, Cebus apella nigritus, in a subtropical rainforest of Argentina. Proc Zool Soc Lond 253:33-45

29. Di Blanco YE, Desbiez ALJ, Jiménez-Pérez I, Kluyber D, Favero Massocato G, Di Bitetti MS (2017) Habitat selection and home-range use by resident and reintroduced giant anteaters in South American wetlands. J Mamm 98:1118-1128

30. Dolton HR, Gell FR, Hall J, Hall G, Hawkes LA, Witt MJ (2020) Assessing the importance of Isle of Man waters for the basking shark Cetorhinus maximus. Endang Species Res 41:209-223

31. ESRI Environmental Systems Research Institute (2021) ArcGIS Desktop: Release 10.8.1. Environmental Systems Research Institute. Redlands, CA

32. Fürstenau Oliveira JS, Georgiadis G, Campello S, Brandão RA, Ciuti S (2017) Improving river dolphin monitoring using aerial surveys. Ecosphere 8:1-18

33. Geisler JH, McGowen MR, Yang G, Gatesy J (2011) A supermatrix analysis of genomic, morphological, and paleontological data from crown Cetacea. BMC Evol Biol 11: 112

34. Gómez-Salazar C, Trujillo F, Whitehead H (2011) Photo-Identification: A Reliable and Noninvasive Tool for Studying Pink River Dolphins (Inia geoffrensis). Aquat Mamm 37:472-485 
35. Gómez-Salazar C, Trujillo F, Whitehead H (2011a) Ecological factors influencing group sizes of river dolphins (Inia geoffrensis and Sotalia fluviatilis). Marine Mamm Scien 28: 24-42

36. Gómez-Salazar C, Coll M, Whitehead H (2012) River dolphins as indicators of ecosystem degradation in large tropical rivers. Ecol Ind 23:1-29

37. Gowans S, Whitehead H, Hooker SH (2001) Social organization of northern bottlenose whales Hyperoodon ampullatus: Not driven by deep water foraging?. Anim Behav 62:369-377

38. Gravena W, Farias IP, da Silva MNF, da Silva VMF, Hrbek T (2014) Looking to the past and the future: were the Madeira River rapids a geographical barrier to the boto (Cetacea: Iniidae). Conserv Genet 15:619-629

39. Gravena W, Hrbek T, da Silva VMF, Farias IP (2019) Boto (Inia geoffrensis Cetacea: Iniidae) aggregations in two provisioning sites in the lower Negro River Amazonas, Brazil: are they related? PeerJ 7:e6692

40. Gubbins $C$ (2002) Use of home ranges by resident bottlenose dolphins (Tursiops truncatus) in a South Carolina estuary. J Mammal 83:178-187

41. Hemson G, Johnson P, South A, Kenward R, Ripley R, MacDonald D (2005) Are kernels the mustard? Data from global positioning system (GPS) collars suggests problems for kernel home-range analyses with least-squares cross-validation. J Anim Ecol 74:455-463

42. Hrbek T, da Silva VMF, Dutra N, Gravena W, Martin AR, Farias IP (2014) A new species of river dolphin from Brazil or: how little do we know our biodiversity. PLoS ONE 9: e83623

43. Hussey NE, Kessel ST, Aarestrup K, Cooke SJ, Cowley PD, Fisk AT, Harcourt RG, Holland KN, Iverson SJ, Kocik JF, Flemming JEM, Whoriskey FG (2015) Aquatic animal telemetry: a panoramic window into the underwater world. Science 348:1255642

44. Jaramillo-Legorreta A, Cardenas-Hinojosa G, Nieto-Garcia E, Rojas-Bracho L, Ver Hoef J, Moore J, Tregenza N, Barlow J, Gerrodette T, Thomas L (2017) Passive acoustic monitoring of the decline of Mexico's critically endangered vaquita. Conserv Biol 31:183-191

45. Kays R, Crofoot MC, Jetz W, Wikelski M (2015) Terrestrial animal tracking as an eye on life and planet. Science 348:aaa2478

46. Kelt DA, Van Vuren DH (2001) The ecology and macroecology of mammalian home range area. J Amer Nat 157:637-645

47. Kenward RE (2001) A manual for wildlife radio tagging. Academic Press, NY

48. Kernohan BJ, Gitzen RA, Millspaugh JJ (2001) Analysis of animal space use and movements. In: Marzluff JM (ed) Radio tracking and animal populations, Academic Press, San Diego, pp 125-166

49. Knight CM, Kenward RE, Gozlan RE, Hodder KH, Walls SS, Lucas MC (2009). Home range estimation within complex restricted environments: importance of method selection in detecting seasonal changes. Wildl Res 36:213-224

50. Kong D, Luo W, Liu Q, Li Z, Huan G, Zhang J, Yang X (2018) Habitat use, preference, and utilization distribution of two crane species (Genus: Grus) in Huize National Nature Reserve, Yunnan-Guizhou 
Plateau, China. PeerJ 6:e5105

51. Loseto LL, Richard P, Stern GA, Orr J, Ferguson SH (2006) Segregation of Beaufort Sea beluga whales during the open-water season. Canad $\mathrm{J}$ of Zool 84:1743-1751

52. Martin AR, Da Silva VMF (1998) Tracking aquatic vertebrates in dense tropical forest using VHF telemetry. MTS J 32:82-88

53. Martin AR, Da Silva VMF (2004) Number, seasonal movements, and residency characteristics of river dolphins in an Amazonian floodplain lake system. Canad J of Zool 82:1307-1315

54. Martin AR, Da Silva VMF (2004a) River dolphins and flooded forest: seasonal habitat use and sexual segregation of botos (Inia geoffrensis) in an extreme cetacean environment. J Zoo Lond 263:295305

55. Martin AR, Da Silva VMF (2006). Sexual dimorphism and body scarring in the boto (Amazon River dolphin) Inia geoffrensis. Mar Mamm Sci. 22:25-33

56. Martin AR, Da Silva VMF (2018). Reproductive parameters of the Amazon river dolphin or boto. Inia geoffrensis (Cetacea: Iniidae); an evolutionary outlier bucks no trends. Biol J Linn Soc. 123:666-676

57. McGuire TL, Winemiller KO (1998) Occurrence patterns, habitat associations, and potential prey of the river dolphin, Inia geoffrensis, in the Cinaruco River, Venezuela. Biotropica 30:625-638

58. McGuire TL, Henningsen T (2007) Movement patterns and site fidelity of river dolphins (Inia geoffrensis and Sotalia fluviatilis) in the Peruvian Amazon as determined by photo-identification. Aqua Mamm 33:359-367

59. McGuire TL, Aliaga-Rossel E (2007) Seasonality of Reproduction in Amazon River Dolphins (Inia geoffrensis) in Three Major River Basins of South America. Biotropica 39:129-135

60. Mintzer VJ, Lorenzen K, Frazer TK, Da Silva VMF, Martin AR (2016) Seasonal movements of river dolphins (Inia geoffrensis) in a protected Amazonian floodplain. Mar Mamm Sci 32:664-681

61. Mintzer VJ, Diniz K, Frazer TK (2018) The Use of Aquatic Mammals for Bait in Global Fisheries. Front Mar Sci 5:191

62. Morales JM, Haydon DT, Frair J, Holsinger KE, Fryxell JM (2004) Extracting more out of relocation data: building movement models as mixtures of random walks. Ecology 85:2436- 2445

63. Morales JM, Moorcroft PR, Matthiopoulos J, Frair JL, Kie JG, Powell RA, Merrill EH, Haydon DT (2010) Building the bridge between animal movement and population dynamics. Philos Trans R Soc Lond B Biol Sci 365: 2289-2301

64. Morris DW (2003) How can we apply theories of habitat selection to wildlife conservation and management?. Wildl Res 4:303-319

65. Mosquera-Guerra F, Trujillo F, Parks D, Oliveira da Costa M, Van Damme PA, Echeverría A, Franco N, Carvajal-Castro JD, Mantilla-Meluk H, Marmontel M, Armenteras-Pascual D (2019) Mercury in populations of river dolphins of the Amazon and Orinoco basins. EcoHealth 16:743-758

66. Mosquera-Guerra F, Trujillo F, Aya-Cuero C, Franco-León N, Valencia K, Vásquez A, Duran-Prieto C, Morales MDJ, Pachón-Bejarano GA, Mantilla-Meluk H, Armenteras-Pascual D (2019a) Population 
estimate and identification of major conservation threats for the river dolphin (Inia geoffrensis humboldtiana) at the Colombian Orinoquia. Therya 11: 9-21

67. Mosquera-Guerra F, Trujillo F, Oliveira-da-Costa M, Marmontel M, Van Damme PA, Franco N, Córdova L, Campbell E, Alfaro-Shigueto J, Mena JL, Mangel JC, Usma Oviedo JS, Carvajal-Castro JD, MantillaMeluk H, Armenteras-Pascual D (2021) Home range and movements of Amazon river dolphins (Inia geoffrensis) in the Amazon and Orinoco river basins. Endang Species Res 45:269-282

68. Nelson T and Boots B (2008) Detecting spatial hot spots in landscape ecology. Ecography 31:556566

69. Newmark WD (2008) Isolation of African protected areas. Front Ecol Environ 6:321-328

70. Newmark WD, Rickart EA (2012) High-use movement pathways and habitat selection by ungulates. Mamm Biol 77:293-298

71. Nina K, Fernández N, Kramer-Schadt S, Herrmann M, Trinzen M, Büttner I, Niemitz C (2008) Habitat selection models for European wildcat conservation. Biol Conserv 141:308-319

72. Oliveira-da-Costa M, Marmontel M, da-Rosa DSX, Coelho A, Wich S, Mosquera-Guerra F, Trujillo F (2019) Effectiveness of unmanned aerial vehicles to detect Amazon dolphins. Oryx 1-3

73. Oshima JEDF, Oliveira Santos MCD, Bazzalo M, Carvalho Flores PAD, Nascimento Pupim FD (2010) Home ranges of Guiana dolphins (Sotalia guianensis) (Cetacea: Delphinidae) in the Cananeia estuary, Brazil. J Mar Biol Assoc UK 90:1641-1647

74. Ouellette M, Cardille A (2011) The complex linear home range estimator: representing the home range of river turtles moving in multiple channels. Chelonian Conserv Biol 10:259-265

75. Powell RA (2000) Animal home ranges and territories and home range estimators. In: Boitani L, Fuller TK (eds) Research and techniques in animal ecology: controversies and consequences, Columbia University Press, New York, pp 65-110

76. Powell RA, Mitchell MS (2012) What is home range?. J Mammal 93:948-958

77. Preisler HK, Ager AA, Wisdom MJ (2006) Statistical methods for analysing responses of wildlife to human disturbance. J Appl Ecol 43:164-172

78. R Core Team (2020) R: a language and environment for statistical computing. Vienna: R Foundation for Statistical Computing, AUT

79. Rako-Gospić N, Radulović M, Vučur T, Pleslić G, Draško H, Mackelworth P (2017) Factor associated variations in the home range of a resident Adriatic common bottlenose dolphin population. Mar Pollut 1: 234-244

80. Rayment W, Dawson S, Slooten E, Bräger S, Du Fresne S, Webster T (2009) Kernel density estimates of alongshore home range of Hector's dolphins at Banks Peninsula, New Zealand. Mar Mamm Sci 25:537-556

81. Reeves RR, Smith B, Crespo EA, Notarbartolo Di Sciara G (2003) Dolphins, whales and porpoises. 2002-2010 Conservation Action Plan for the World's Cetaceans. IUCN/SSC Cetacean Specialist Group, GLAND 
82. Relyea RA, Lawrence RK, Demarais S (2000) Home range of desert mule deer: testing the body-size and habitat-productivity hypotheses. J Wildl Manage 64:146-153

83. Revenga C, Brunner J, Henninger N, Kassem K, Payne R (2000) Pilot Analysis of Global Ecosystems: Freshwater Systems. World Resources Institute, WA

84. Reyers B, O'Farrell P J, Cowling RM, Egoh BN, Le Maitre DC, Vlok JHJ (2009) Ecosystem services, land-cover change, and stakeholders: Finding a sustainable foothold for a semiarid biodiversity hotspot. Ecol Soc 14: 38

85. Rigby RA, Stasinopoulos DM (2005) Generalized additive models for location, scale and shape. J R Stat Soc C-Appl 3:507-554

86. Rigby RA, Stasinopoulos DM (2010) A flexible regression approach using GAMLSS in R. University of Lancaster, LA

87. Sawyer H, Kauffman MJ, Nielson RM, Horne JS (2009) Identifying and prioritizing ungulate migration routes for landscape-level conservation. Ecol Appl 19:2016-2025

88. Sawyer H, Kauffman MJ (2011) Stopover ecology of a migratory ungulate. J Anim Ecology 80:1078-1087

89. Seaman DE, Powell RA (1996) An evaluation of the accuracy of kernel density estimators for home range analyses. Ecology 77:2075-2085

90. Seminoff JA, Resendiz A, Nichols WJ (2002) Home range of green turtles Chelonia mydas at a coastal foraging area in the Gulf of California, Mexico. Mar Ecol Prog Ser 242: 253-265

91. Sevigny J, Summers A, Kalisz G, McAllister K (2021) Identification of Elk-vehicle incident hotspots on state route 20 in Washington State. Landsc Ecol 36:1685-1698

92. Sioli $\mathrm{H}$ (1984) The Amazon and its main affluents: hydrography, morphology of the river courses, and river types. In: Sioli $\mathrm{H}$ (ed) The Amazon: Limnology and landscape ecology of a mighty tropical river and its basin. Dr. Junk W, Publishers, Dordrecht, pp 127-166

93. Soulé ME, Terborgh J (1999) Continental Conservation: Scientific Foundations of Regional Reserve Networks. Island Press, WA

94. Sprogis KR, Raudino HC, Rankin R, MacLeod CD, Bejder L (2015) Home range size of adult IndoPacific bottlenose dolphins (Tursiops aduncus) in a coastal and estuarine system is habitat and sexspecific. Mar Mamm Sci 32:287-308

95. Stasinopoulos MD, Rigby RA (2007) Generalized additive models for Location Scale and Shape (GAMLSS). J Stat Sofw 2:1-64

96. Stahl P, Vandel JM, Herrenschmidt V, Migot $P$ (2001) Predation on livestock by an expanding reintroduced lynx population: long-term trend and spatial variability. J Appl Ecol 38: 674-687

97. Trujillo F (1994) The use of photo-identification to study the Amazon river dolphin. Inia geoffrenis in the Colombian Amazon. Marine Mamm Sci 10:348-353

98. Trujillo F (2000) Habitat use and social behavior of the freshwater dolphin Inia geoffrensis (de Blainville 1817) in the Amazon and Orinoco basins. Phylosophal Doctoral Thesis, University of 


\section{Aberdeen}

99. Trujillo F, Crespo E, Van Damme P, Usma J.S (2010) The Action Plan for South American River Dolphins 2010-2020. Graphic Union, BTA

100. Tucker MA, Ord TJ, Rogers TL (2014) Evolutionary predictors of mammalian home range size: body mass, diet and the environment. Global Ecol Biogeogr 23:1-10

101. Turvey ST, Pitman RL, Taylor BL, Barlow J, Akamatsu T, Barrett LA, Zhao X, Reeves RR, Stewart BS, Wang K, Wei Z, Zhang X, Pusser LT, Richlen M, Brandon JR, Wang D.

102. (2007) First human-caused extinction of a cetacean species?. Biol Lett 3: 537-540

103. USGS (2021) Landsat Archive. LANDSAT 8 (2017-2021). United States Geological Survey. http://earthexplorer.usgs.gov/. Accessed 20 June 2021

104. Van Beest FM, Rivrud IM, Loe LE, Milner JM, Mysterud A (2011) What determines variation in home range size across spatiotemporal scales in a large browsing herbivore? J Anim Ecol 80:771-85

105. Van Toor ML, Kranstauber B, Newman SH, Prosser DJ, Takekawa JY, Technitis G, Weibel R, Wikelski M, Safi K (2018) Integrating animal movement with habitat suitability for estimating dynamic migratory connectivity. Landsc Ecol 33:879-893

106. Viana DS, Granados JE, Fandos P, Pérez JM, Cano-Manuel FJ, Burón D, Fandos G, Párraga Aguado MA, Figuerola J, Soriguer RC (2018) Linking seasonal home range size with habitat selection and movement in a mountain ungulate. Mov Ecol 6:1-11

107. Vörösmarty CJ, McIntyre PB, Gessner MO, Dudgeon D, Prusevich A, Green P, Glidden S, Bunn SE, Sullivan CA, Liermann CR (2010) Global threats to human water security and river biodiversity. Nature 467:555-561

108. Wells RS, Schwacke LH, Rowles TK, Balmer BC, Zolman E, Speakman T, Townsend Fl, Tumlin MC, Barleycorn A, Wilkinson KA (2017) Ranging patterns of common bottlenose dolphins Tursiops truncatus in Barataria Bay, Louisiana, following the Deepwater Horizon oil spill. Endang Species Res $33: 159-180$

109. Whitehead H, Weilgart L (2000) The sperm whale: Social females and roving males. In: Mann J, Connor RC, Tyack P, Whitehead H (eds) Cetacean societies. University of Chicago Press, Chicago, pp $154-172$

110. Witt MJ, Åkesson S, Broderick AC, Coyne MS, Ellick J, Formia A, Graeme CH, Luschi P, Stroud S, Godley BJ (2010) Assessing accuracy and utility of satellite-tracking data using Argos-linked FastlocGPS. Anim Behav 80:571-581

111. Yamamoto Y, Akamatsu T, da Silva VMF, Kohshima S (2015) Local habitat use by botos (Amazon river dolphins, Inia geoffrensis) using passive acoustic methods. Mar Mamm Sci 32:220-240

112. Zapata LA. Usma JS (2013) Guía de las especies Migratorias de la Biodiversidad en Colombia, Peces. Ministerio de Ambiente y Desarrollo Sostenible. WWF-Colombia, BTA

113. Zhang L, Fu B, Lü Y, Zeng Y (2015) Balancing multiple ecosystem services in conservation priority setting. J Landsc Ecol 30:535-546 


\section{Figures}

(a)

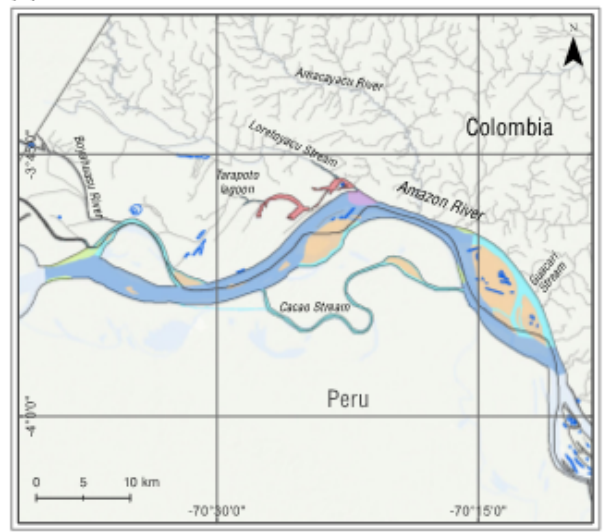

(c)

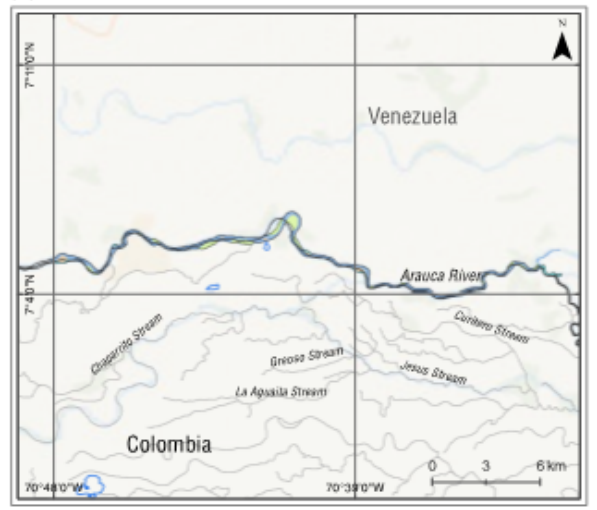

(e)

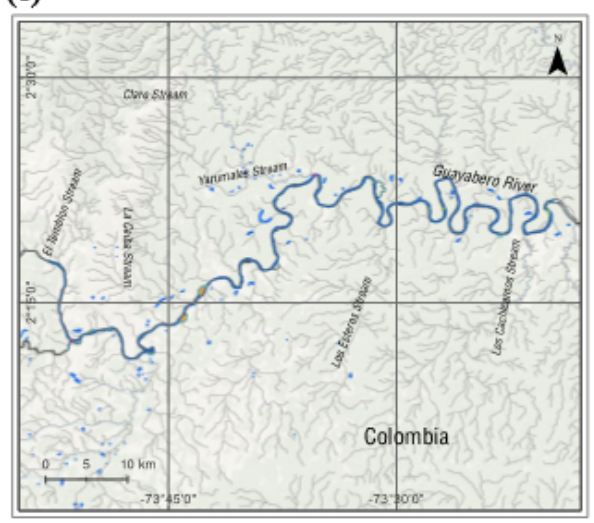

(b)

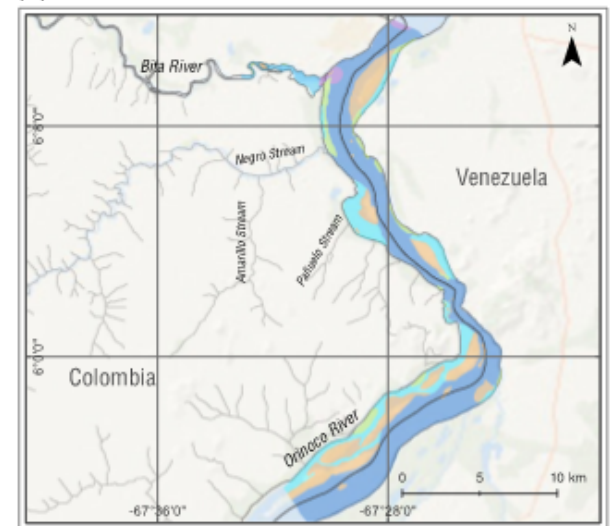

(d)

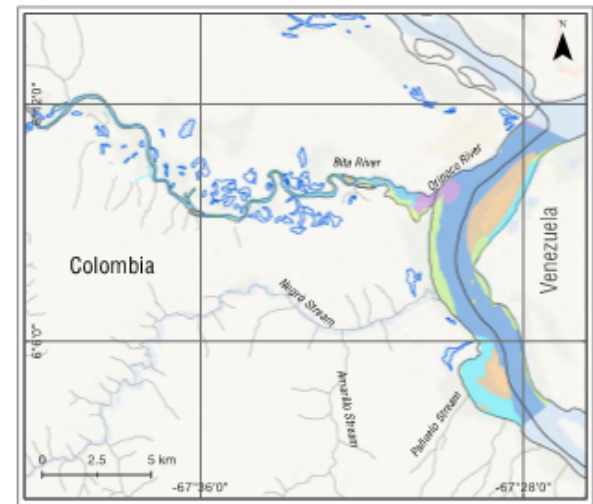

(f)

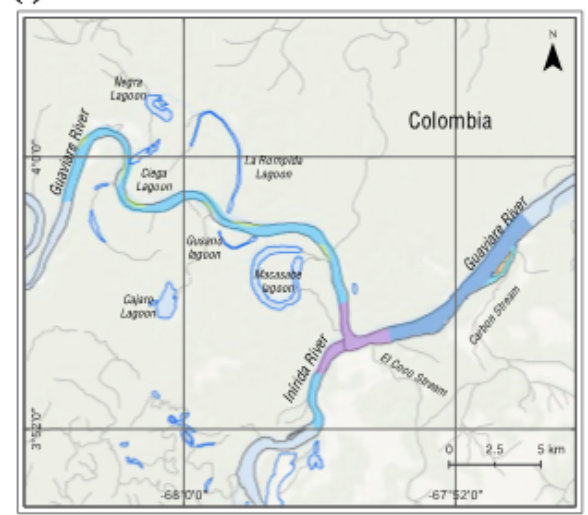

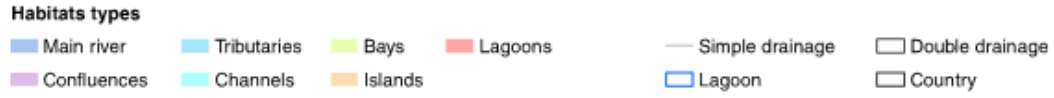

\section{Figure 1}

Transects evaluated and classified by habitat type used by Amazon River dolphins satellite-monitored in the six rivers studied in the Amazon basin: (a) Amazonas River and Orinoco basin; (b) Orinoco, (c) Arauca, 
(d) Bita, (e) Guayabero, and (f) Guaviare rivers. Transects evaluated were delimited with the home range areas $95 \%$ (K95) calculated for each analyzed river dolphin individual

(a) Satellite image processing
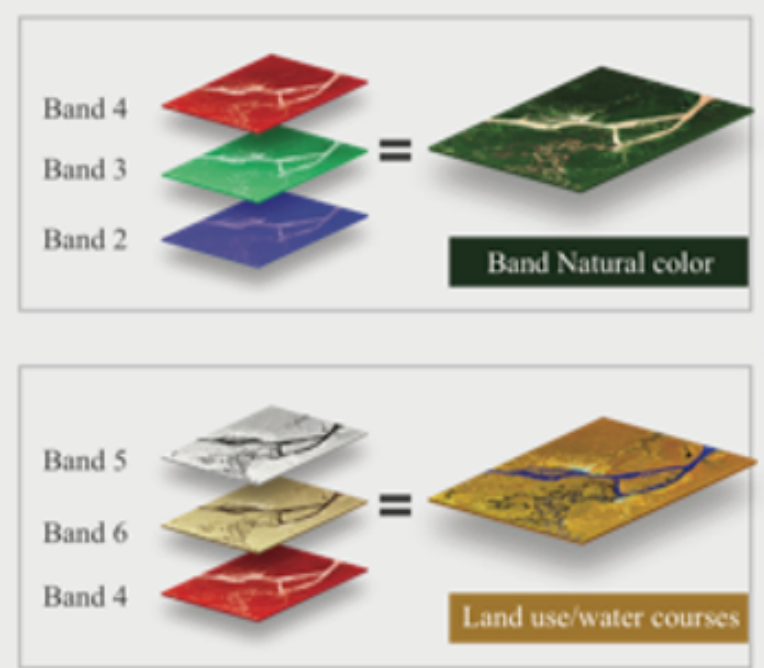

(c) Classification of the locations in the habitat types

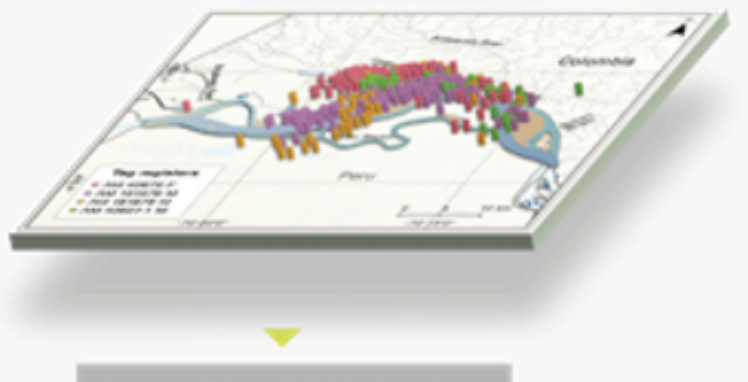

Amazon River dolphin locations

\section{(b) Classification of habitat types}
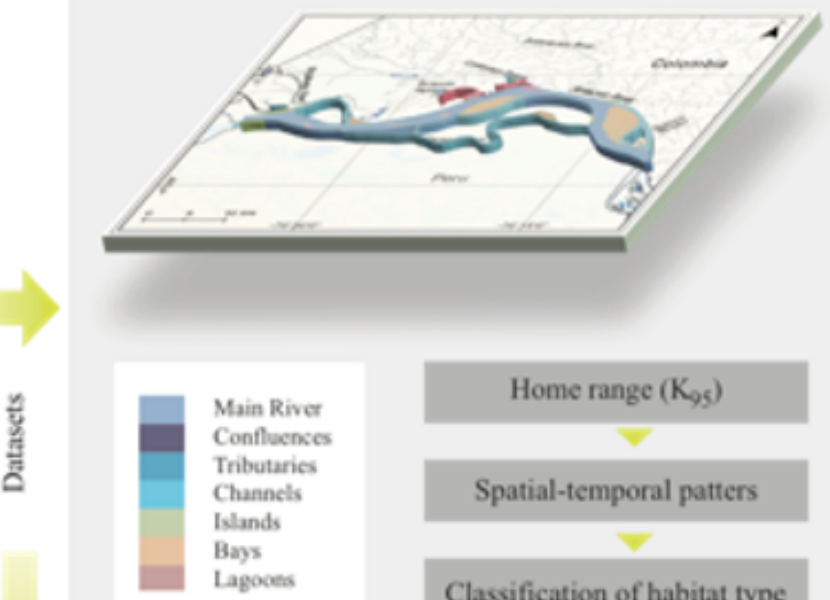

Home range $\left(\mathrm{K}_{95}\right)$

Spatial-temporal patters

Classification of habitat type

(d) Hotspots of Amazon River dolphin activity

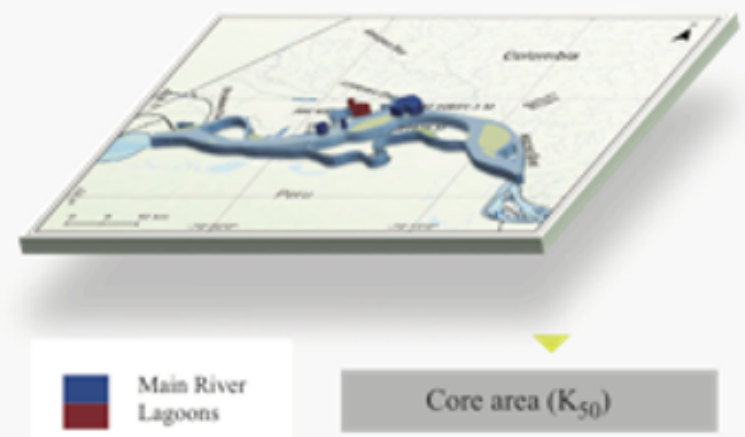

\section{Figure 2}

(a) and (b) Schematic diagram, illustrating the process of classification of habitats used by I. geoffrenis, (c) Mapping of the locations obtained through satellite monitoring of 17 individuals in the identified habitat types, and (d) hotspots of Amazon River dolphin activity 
(a)

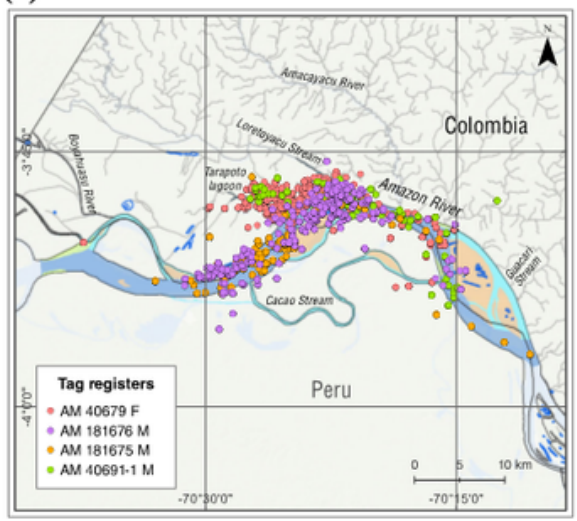

(c)

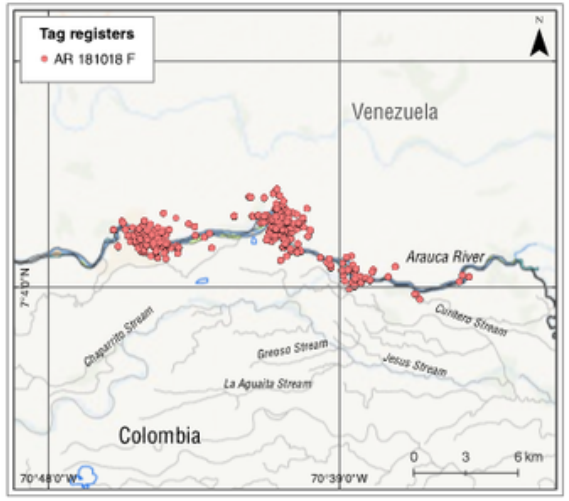

(e)

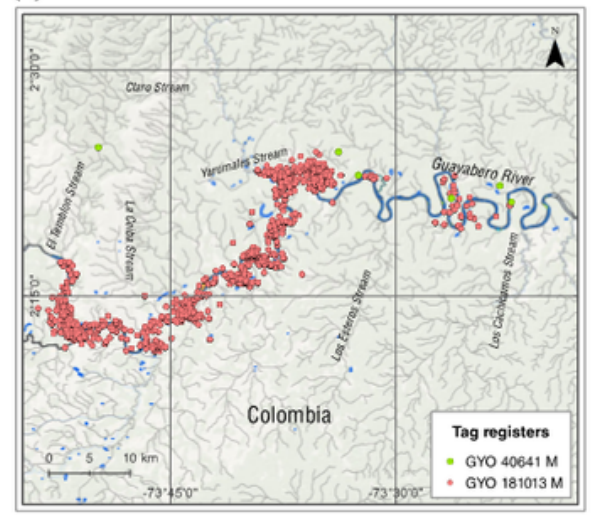

(b)

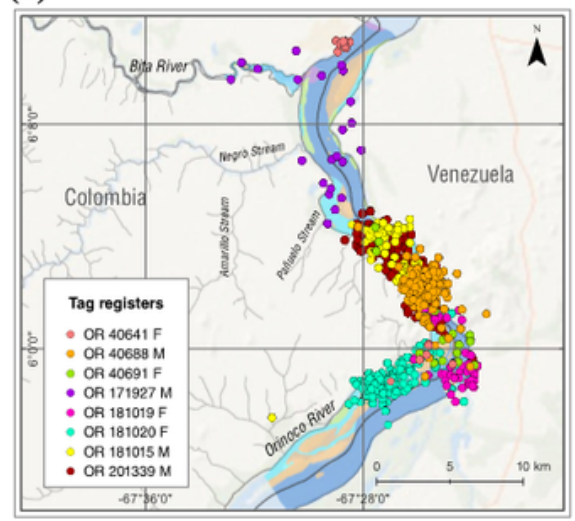

(d)

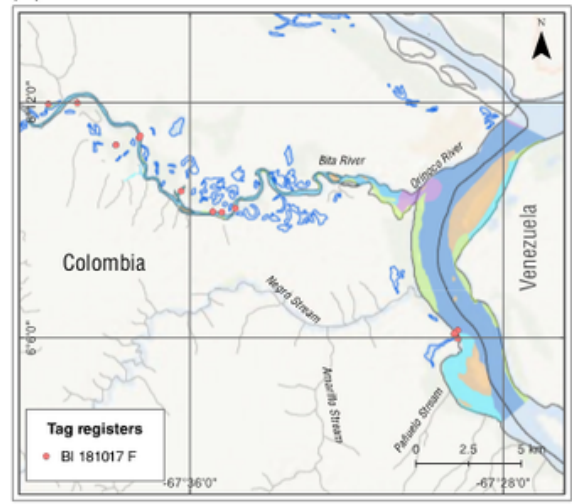

(f)

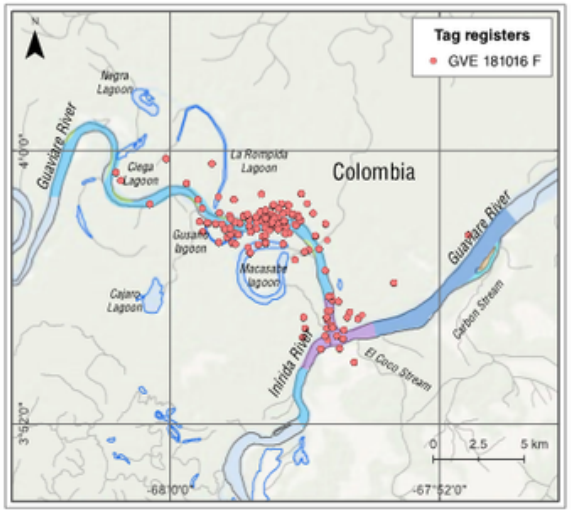

\section{Figure 3}

Classification of the locations of satellite-monitored I. geoffrensis individuals in the seven habitat types for transects evaluated in the six rivers studied: (a) Amazonas River, and Orinoco basin, (b) Orinoco, (c) Arauca, (d) Bita, (e) Guayabero, and (f) Guaviare rivers 


\section{Number of locations}

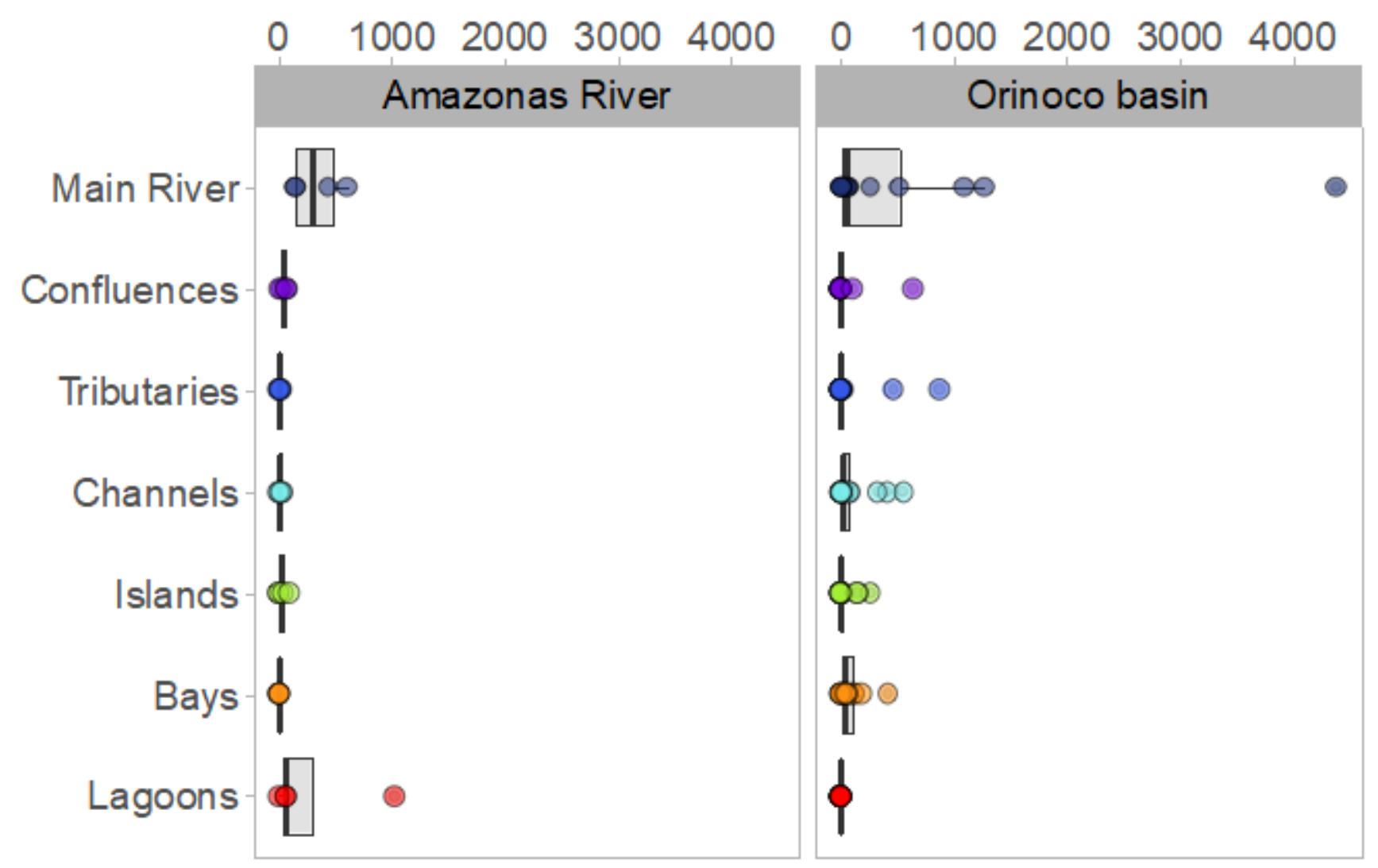

Figure 4

Box plots of the number of I. geoffrensis locations discriminated by habitat types for the Amazonas River and Orinoco basin 
Proportions from number of locations in habitat types

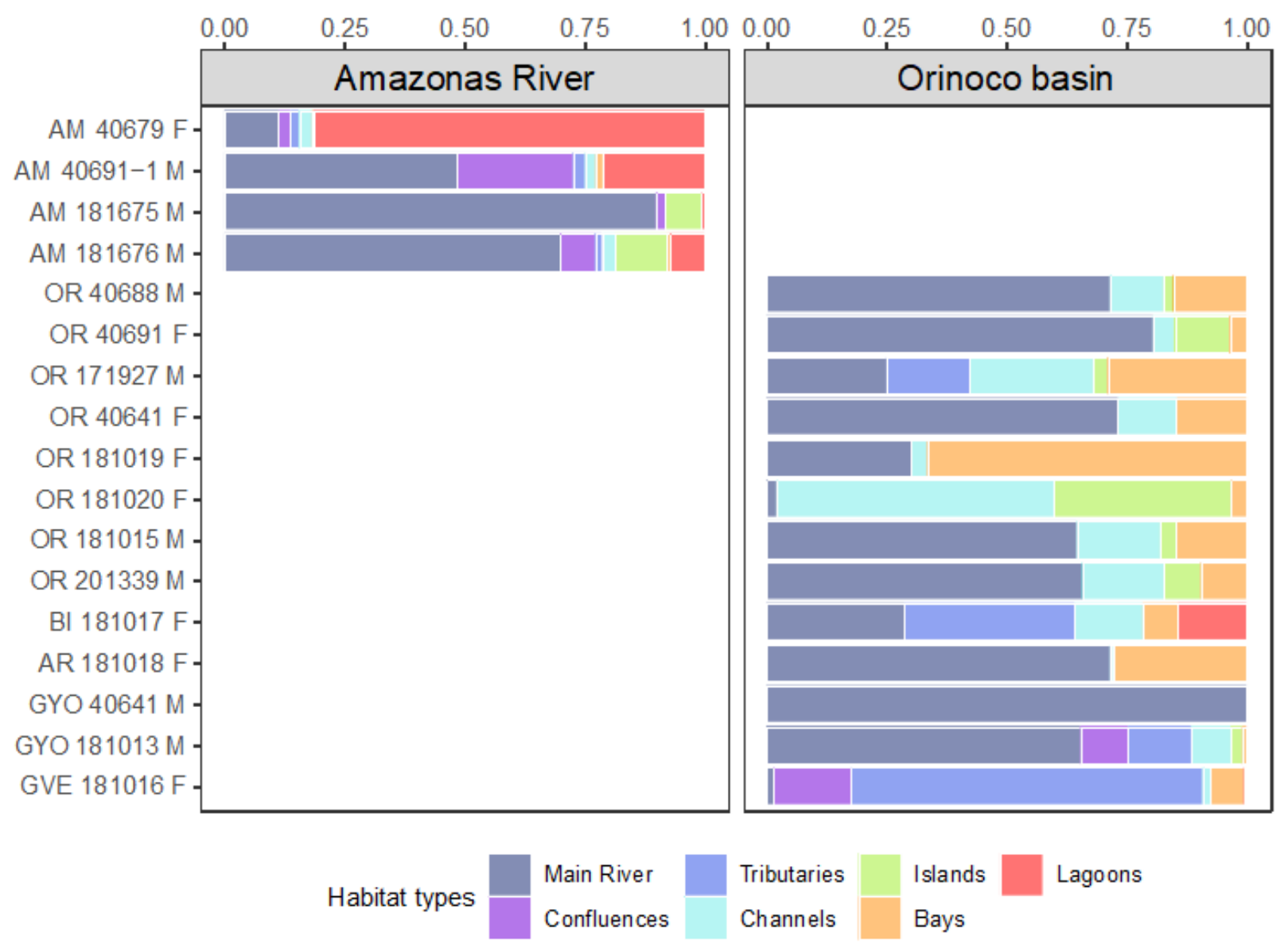

\section{Figure 5}

The proportion of the number of locations recorded by satellite-monitored I. geoffrensis individuals and classified by habitat types in transects evaluated for the Amazonas River and Orinoco basin
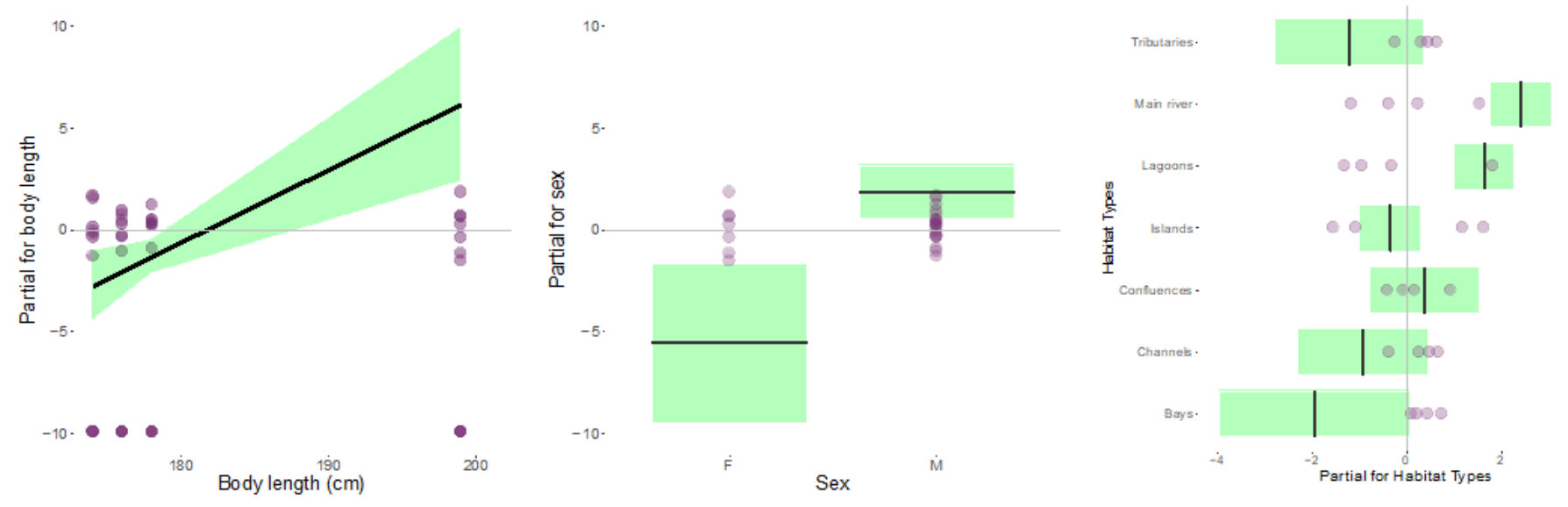

Figure 6 
Smoother estimates for the predictors (a) body length, (b) sex (F: female and M: male), and (c) habitat types, obtained by the GAMLSS predicting the probability of I. geoffrensis individual habitat use in the Amazonas River. Shaded circles represent partial residuals; shaded areas, 95\% confidence intervals around mean partial effect. Shaded circles on the $x$-axis are sampled data points

(a)

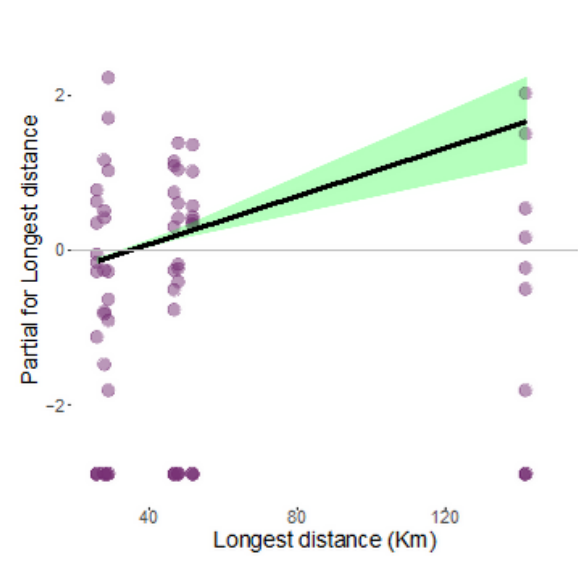

(b)

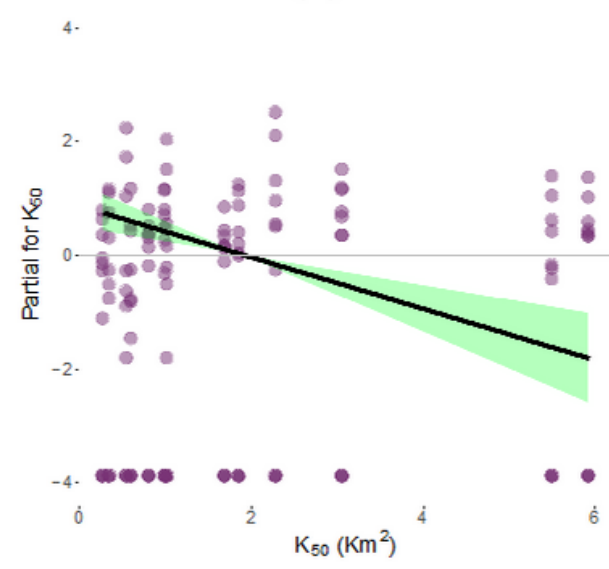

(c)

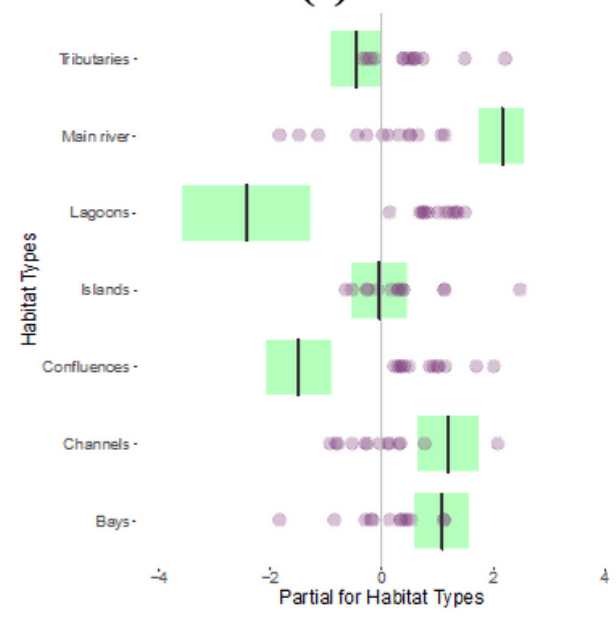

Figure 7

Smoother estimates for the predictors (a) longest distance (km), (b) K50 (km2), and (c) habitat types, obtained by the GAMLSS predicting the probability of I. geoffrensis individuals habitat use in the Orinoco basin. Shaded circles represent partial residuals; shaded areas, $95 \%$ confidence intervals around mean partial effect. Shaded circles on the $x$-axis are sampled data points 
(a)

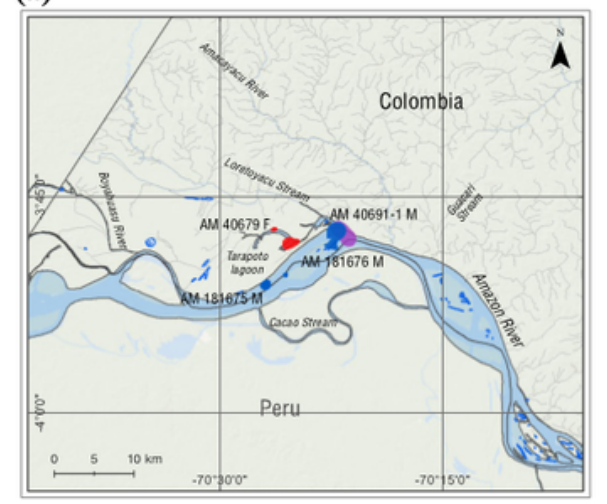

(c)

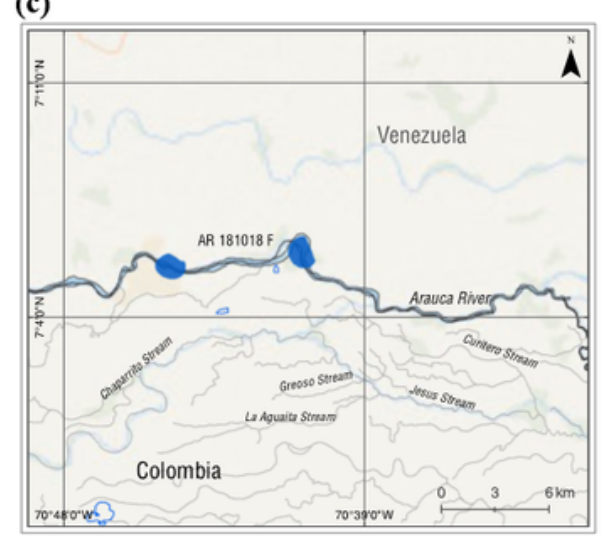

(e)

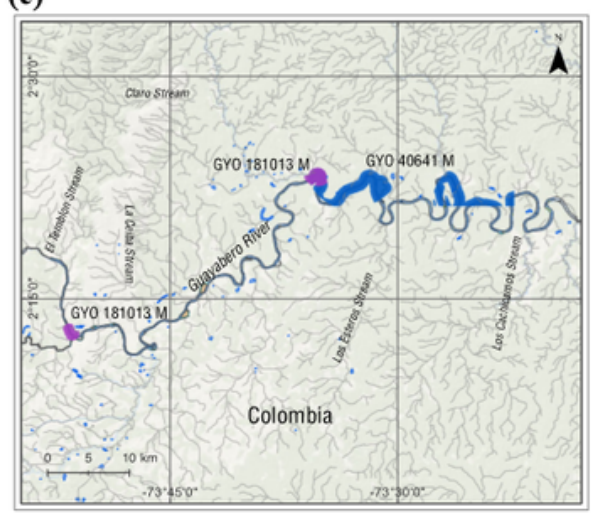

\section{Habitats types}

Main river Tributaries Bays $\amalg$ Lagoons

Confluences Channels Islands (b)

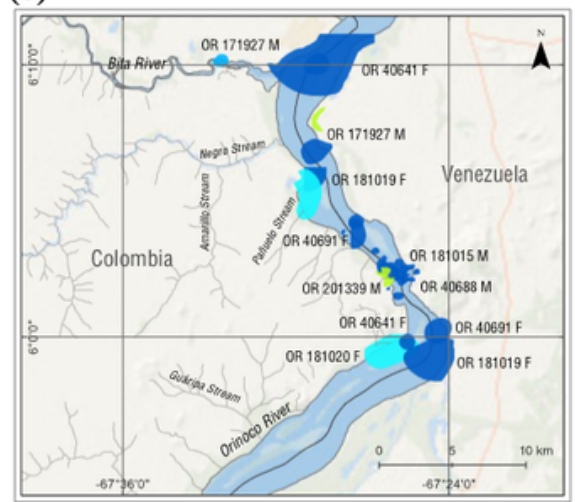

(d)

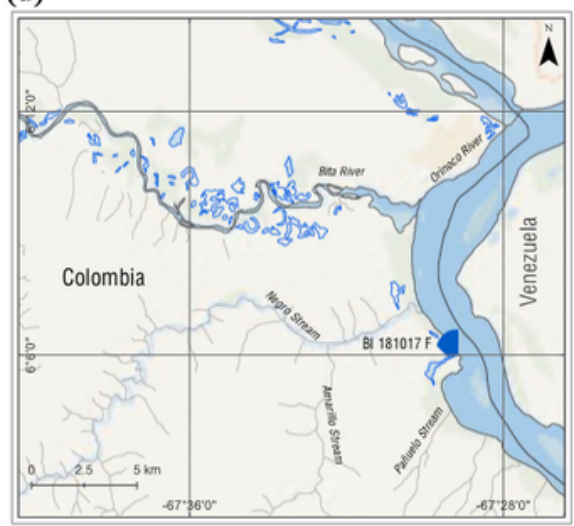

(f)

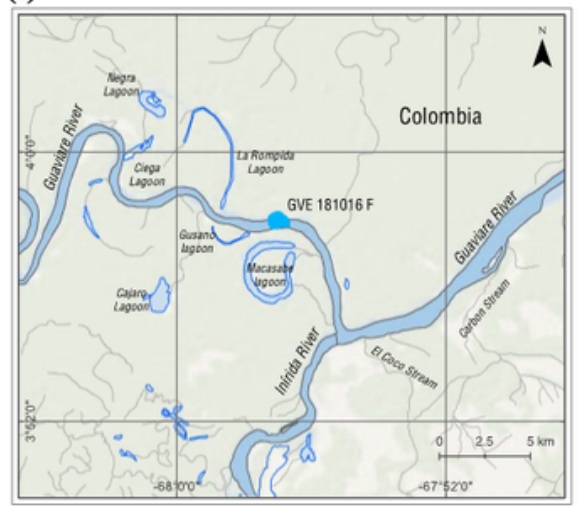

- Simple drainage $\square$ Double drainage

\section{Figure 8}

Hotspots of Amazon River dolphin activity in the six rivers studied: (a) Amazonas River, and Orinoco basin: (b) Orinoco, (c) Arauca, (d) Bita, (e) Guayabero, and (f) Guaviare rivers. Hotspots of individuals were established by calculating the central area $50 \%$ (K50) for each individual

\section{Supplementary Files}


This is a list of supplementary files associated with this preprint. Click to download.

- SupplementaryInformation.docx 